\title{
CADERNO DE IMAGENS
}





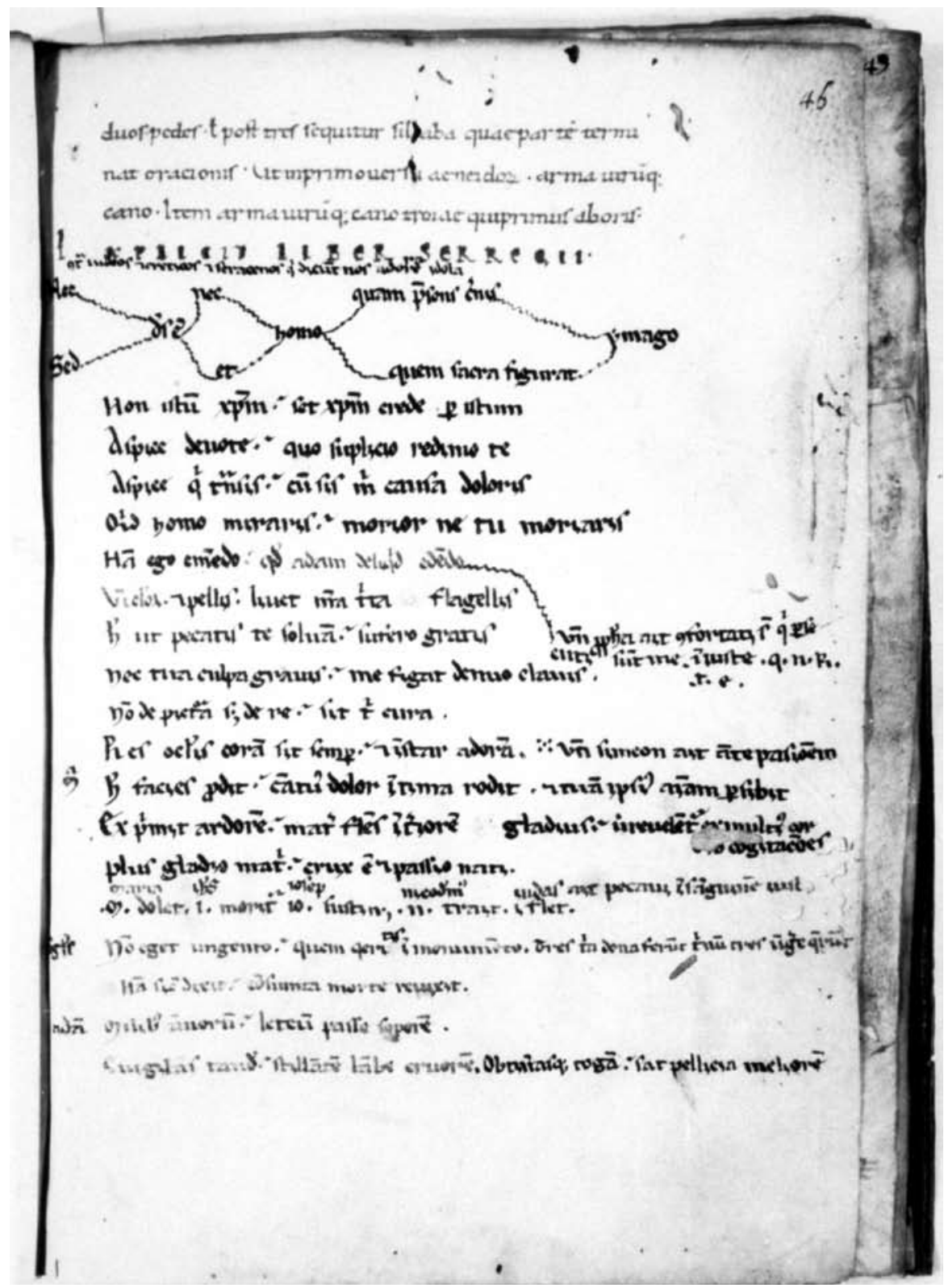

Fig. 1 - Vaticano, BAV. Reg. Lat.1578, fol. 46. 


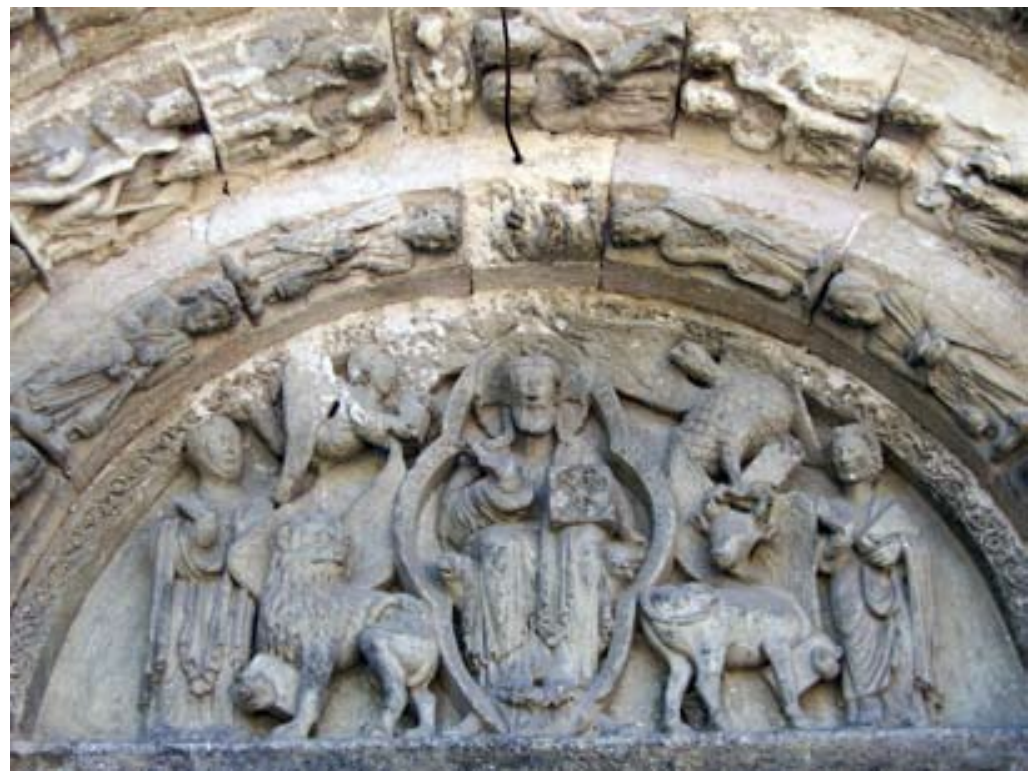

Fig. 2 - Tímpano, San Miguel de Estella.

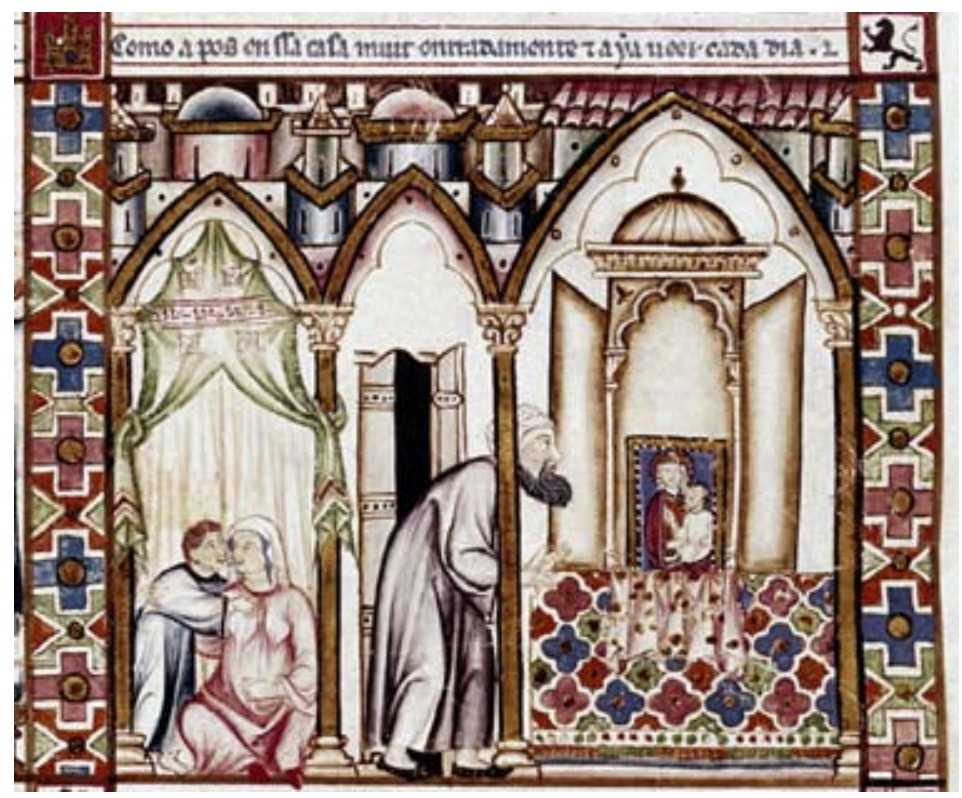

Fig. 3 - Escorial, Biblioteca del Real Monasterio, MS. H.1.15k, fol. 68v. 
Herbert L. KESSLER. Caderno de Imagens

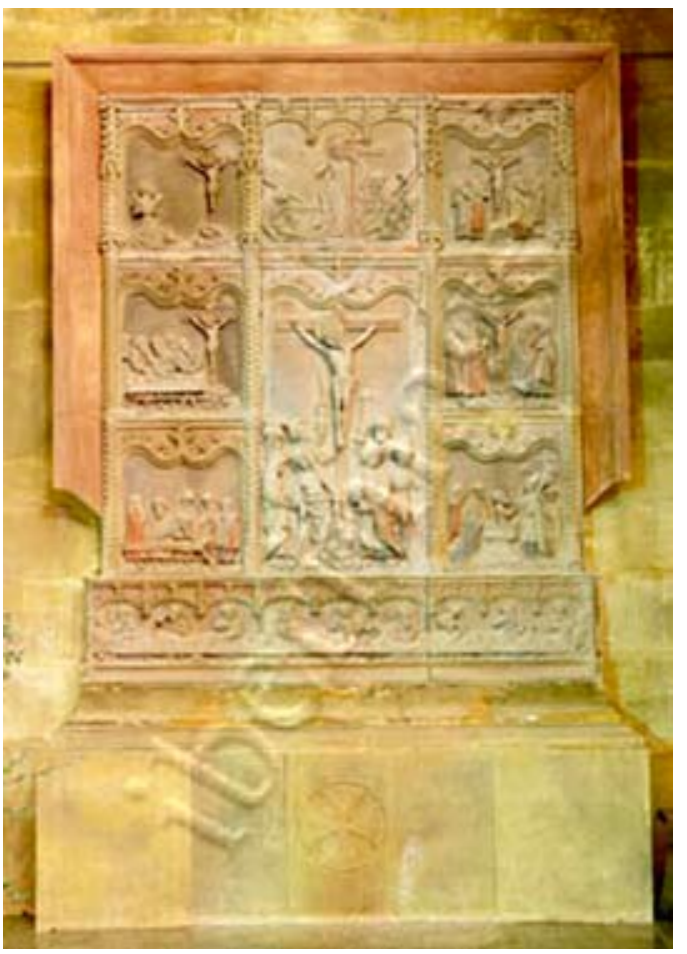

Fig. 4 - Mallorca, Santuário de Felanitx.

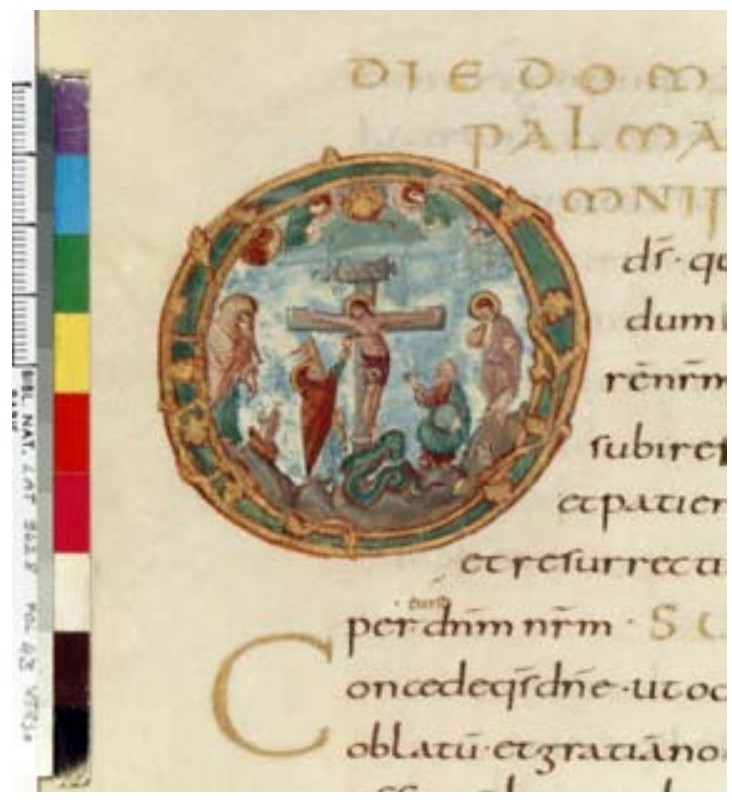

Fig. 5 - Paris, BnF, MS lat. 9428, fol. 43v. 

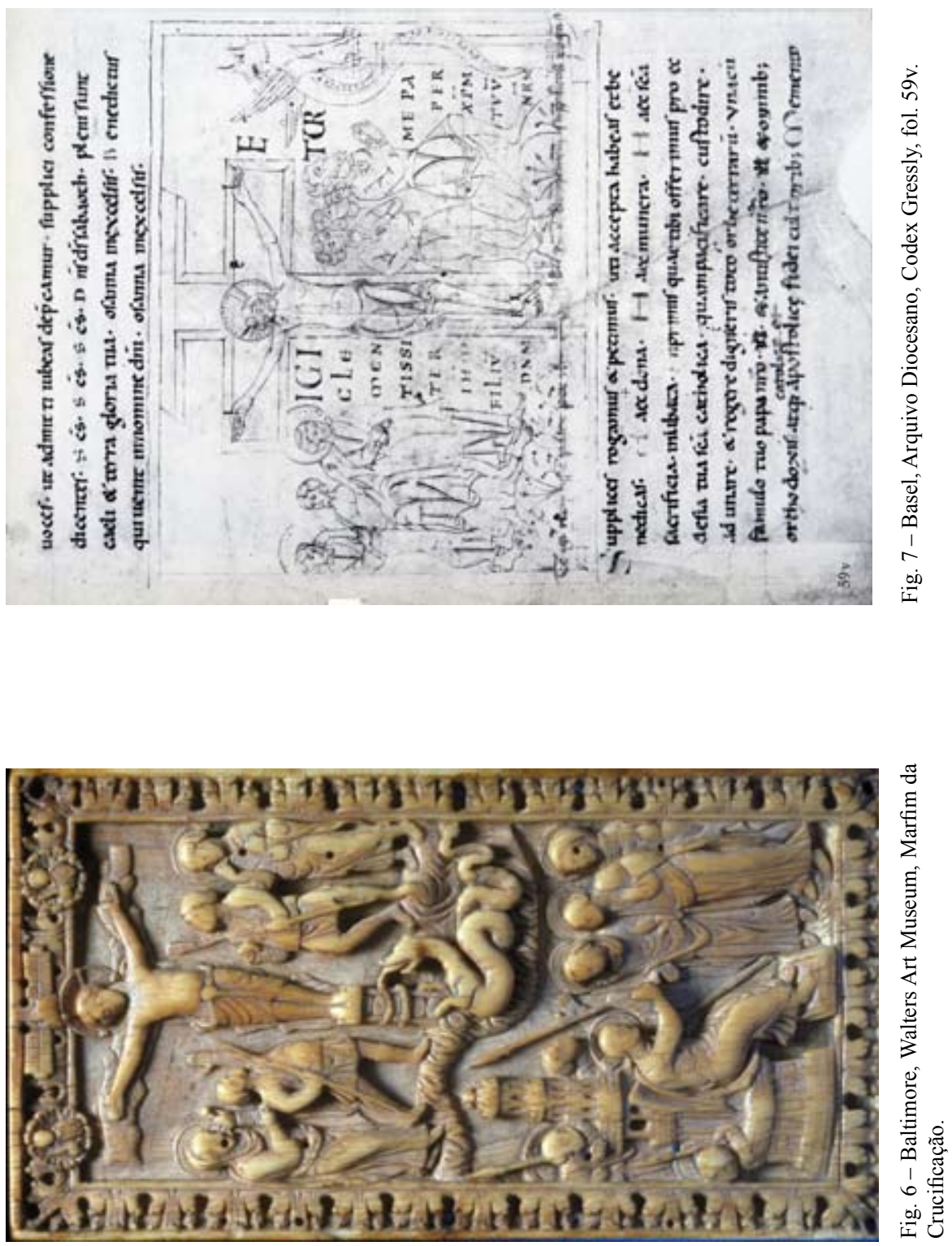


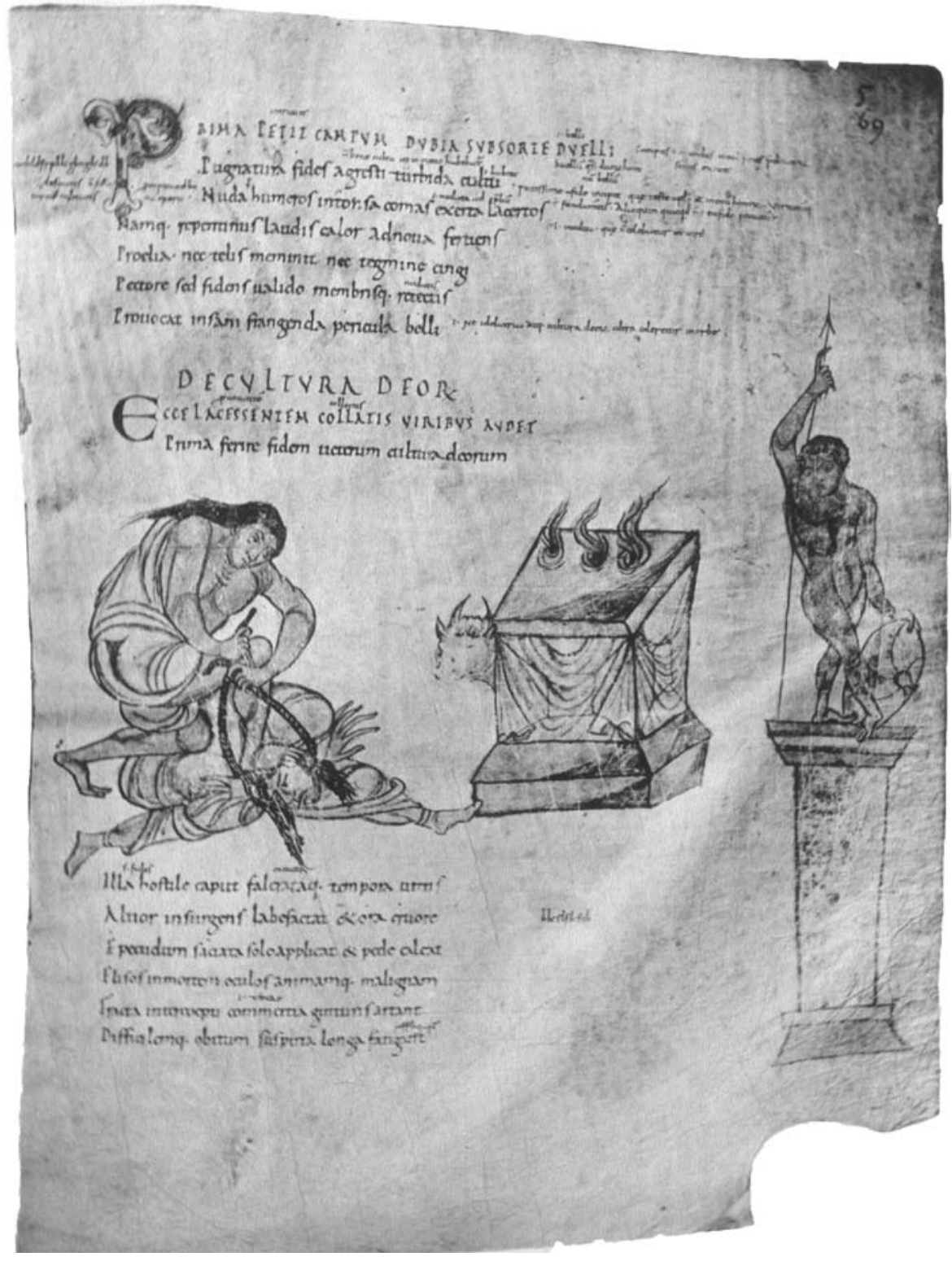

Fig. 8 - Burgerbibliothek, MS 264, p. 69. 


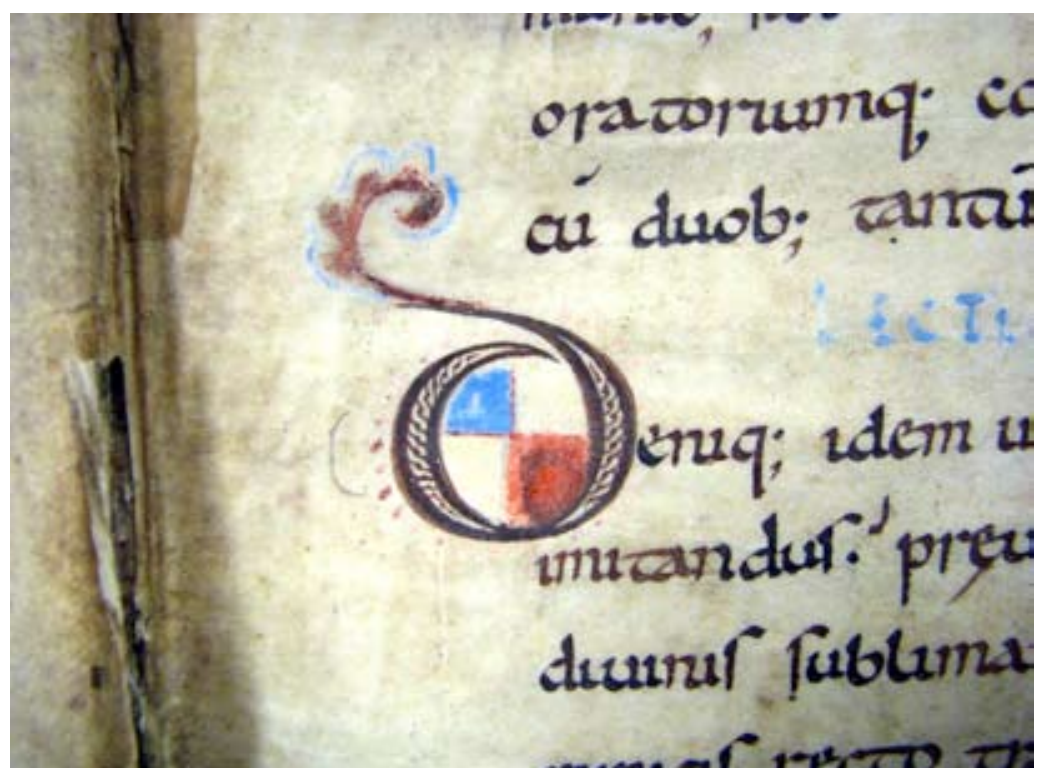

Fig. 1 - Manuscrito 1. Biblioteca de Semur-en-Auxois, por volta do ano mil, f. 2r.

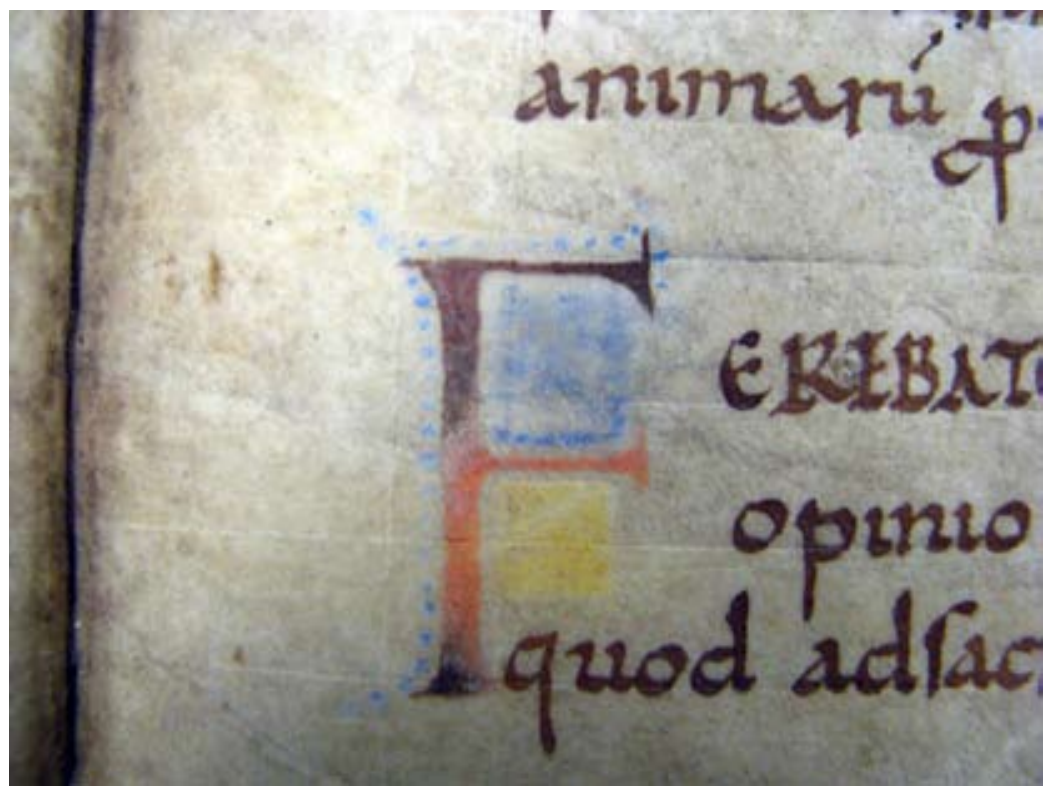

Fig. 2 - Manuscrito 1. Biblioteca de Semur-en-Auxois, por volta do ano mil, f. 35r. 
Daniel RUSSO. Caderno de Imagens.

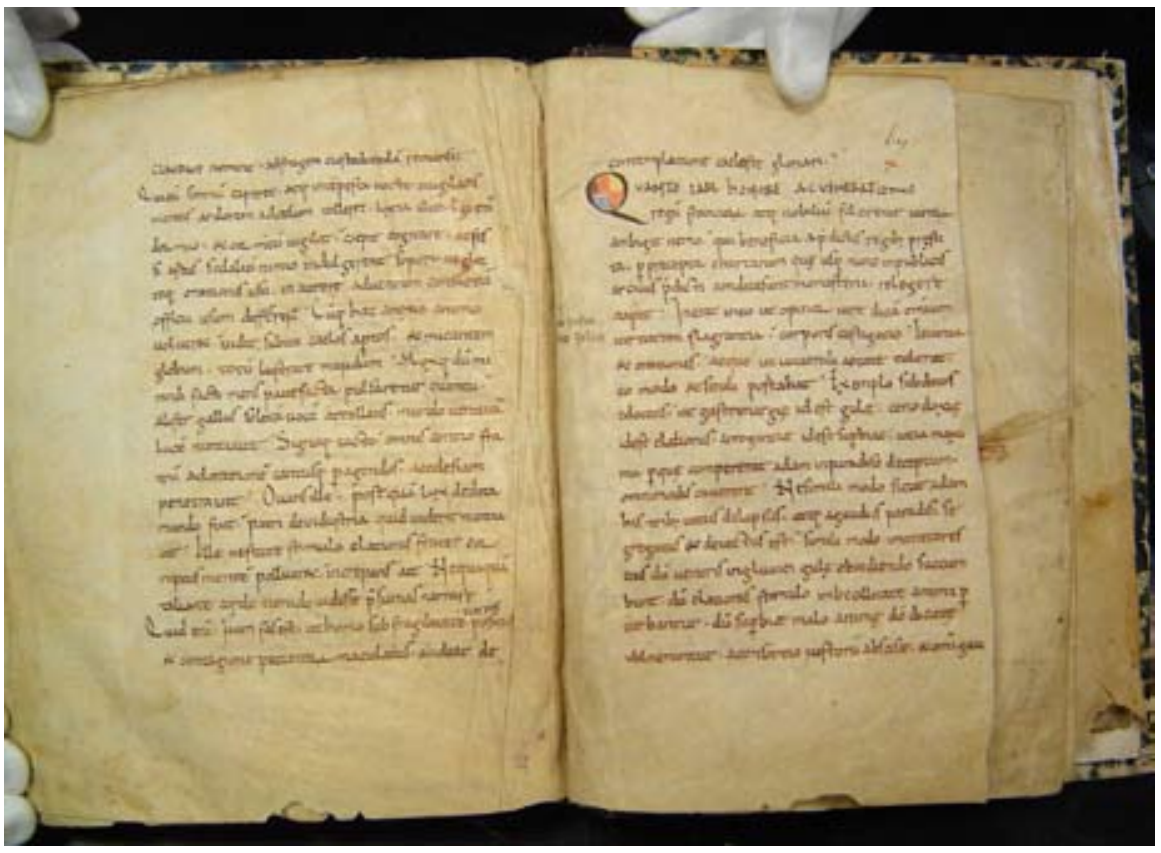

Fig. 3 - Manuscrito 1. Biblioteca de Semur-en-Auxois, por volta do ano mil, f. 69r.

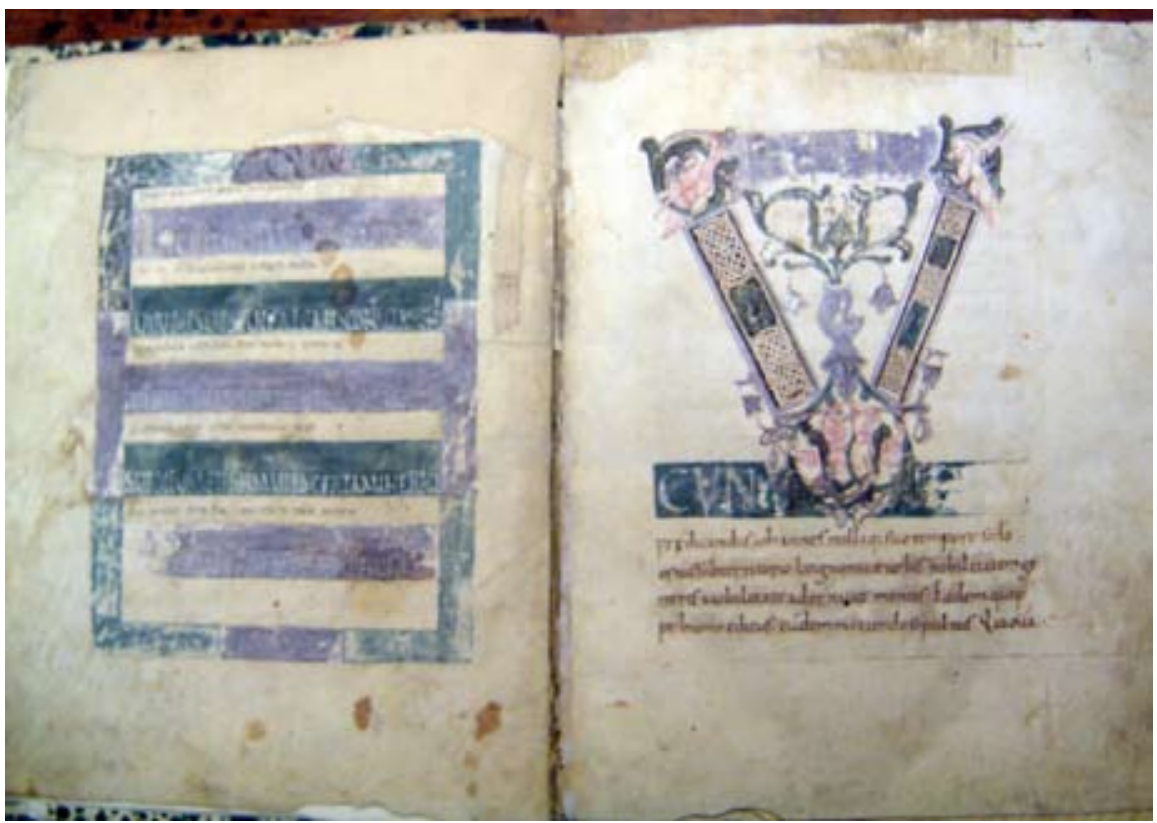

Fig. 4 - Manuscrito 1. Biblioteca de Semur-en-Auxois, por volta do ano mil, ff. 01v-1r. 


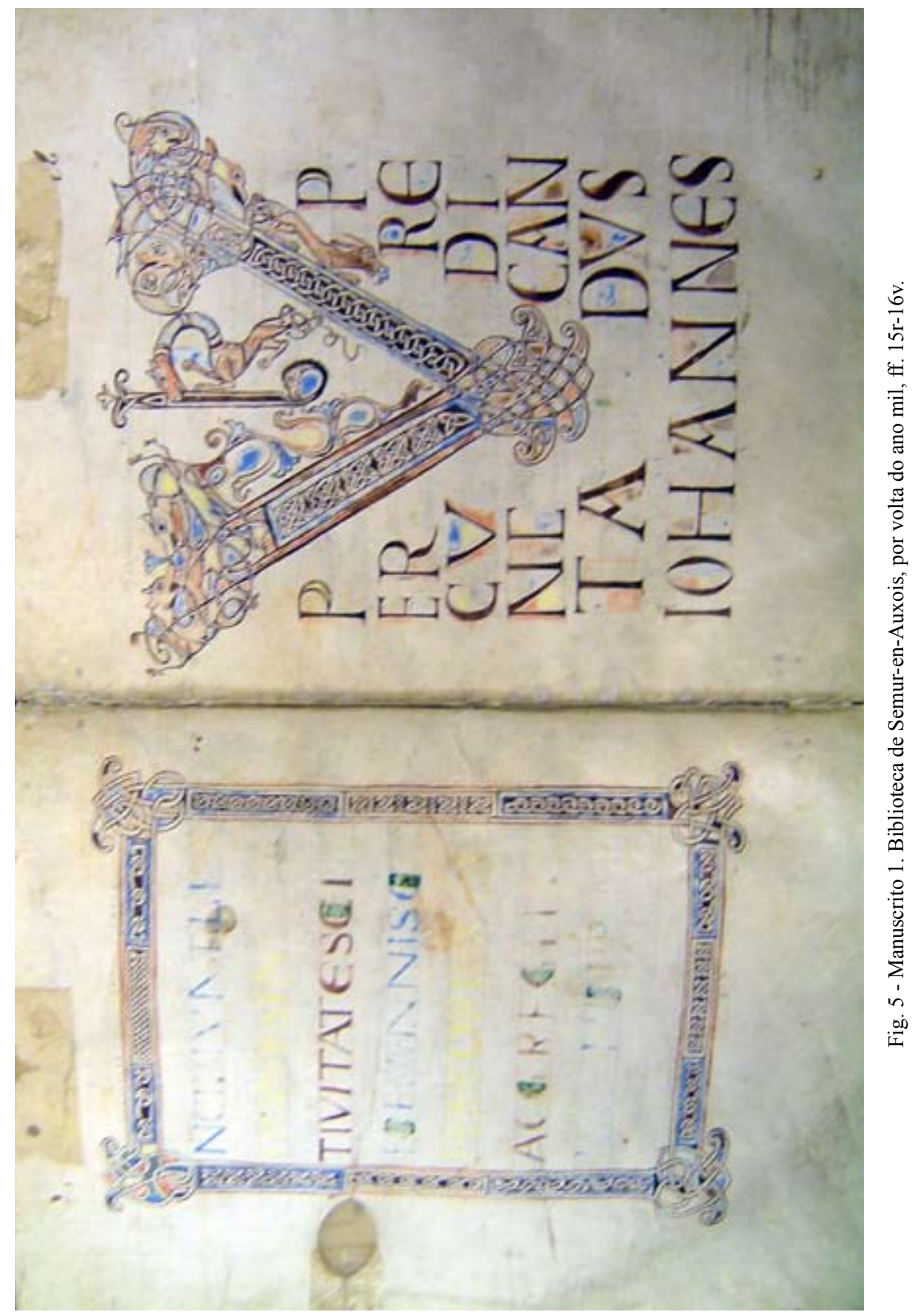


Daniel RUSSO. Caderno de Imagens.

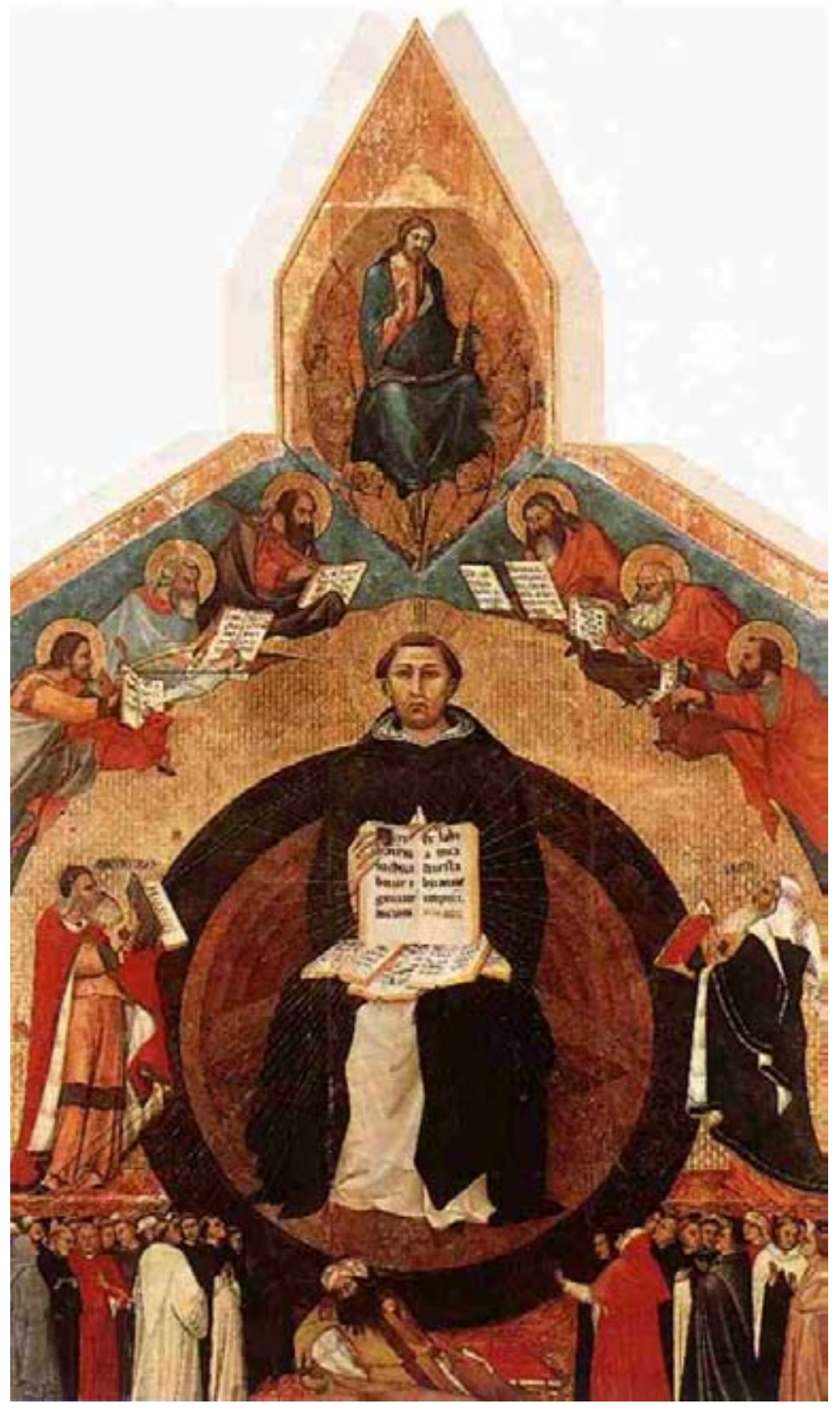

Fig. 6 - TRAINI, Francesco. Triunfo de São Tomás de Aquino. Madeira de álamo, $375 \mathrm{~cm} / 258 \mathrm{~cm}$ (1340), proveniente da igreja de Santa Catarina, Pisa, atualmente no Museu San Martino. 


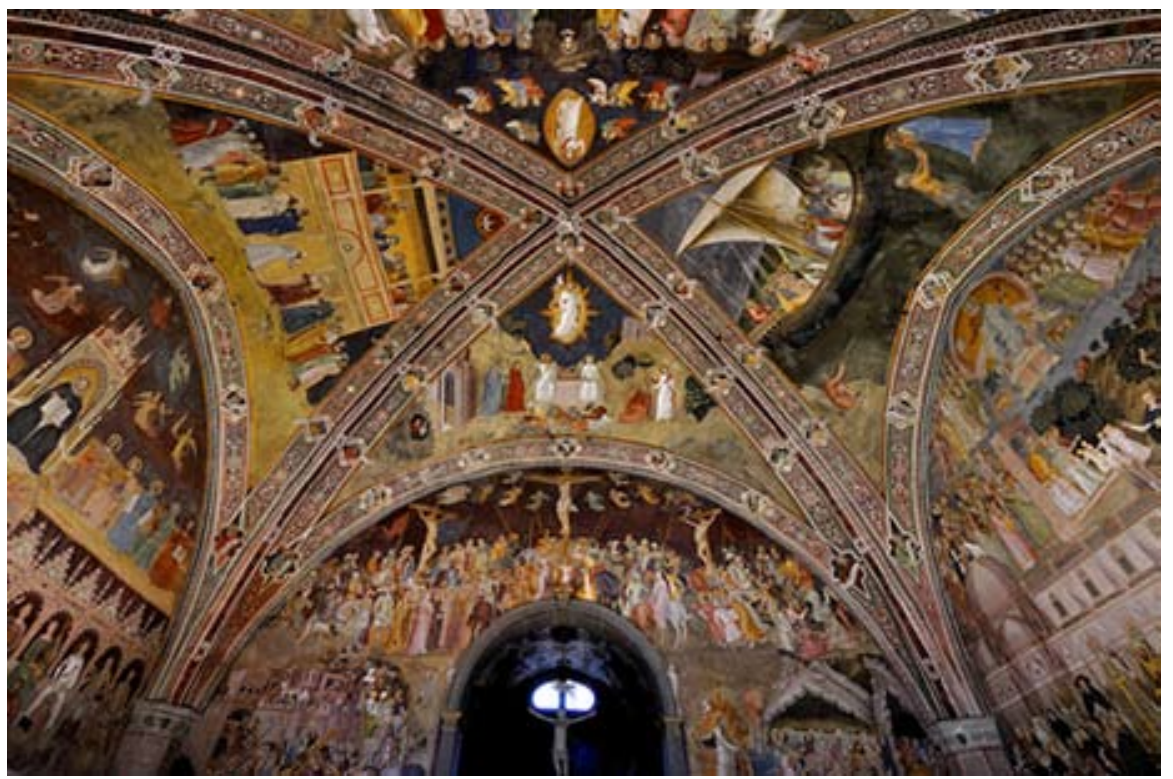

Fig. 7 - DI BONAIUTO, Andrea. Triunfo de São Tomás de Aquino. Afresco (1366-1367), antiga sala capitular, atualmente Capela dos Espanhóis, Florença, convento de Santa Maria Novella.

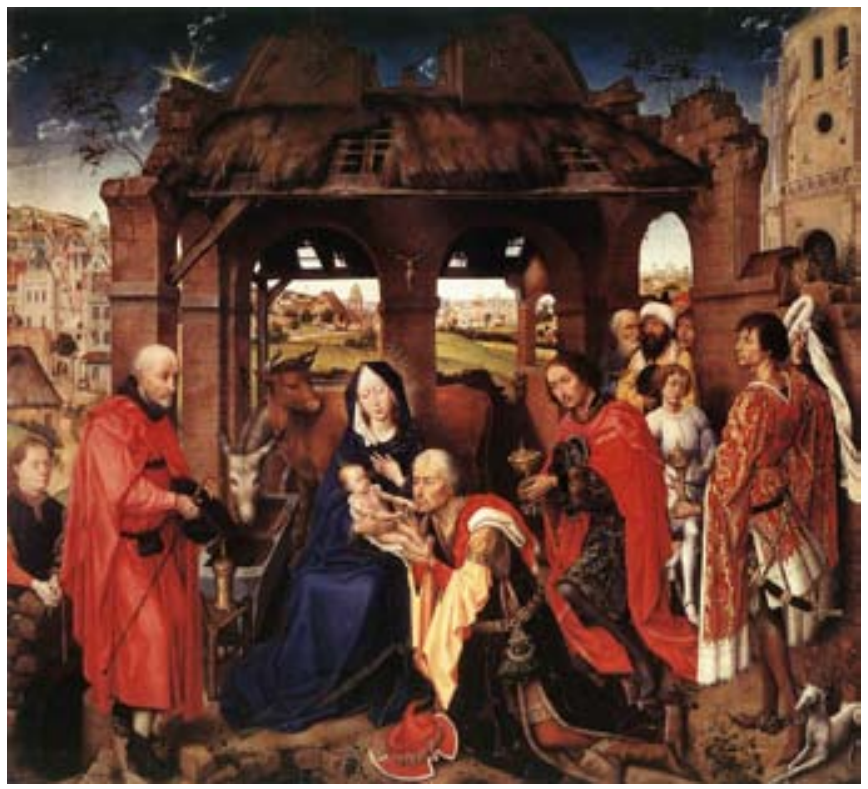

Fig. 8 - VAN DER WEYDEN, Rogier. Adoração dos magos. Compartimento central de retábulo pintado, óleo sobre tela (vers 1455), igreja de Santa Colomba, Colônia. 
Maria Cristina Correia Leandro PEREIRA. Caderno de Imagens.

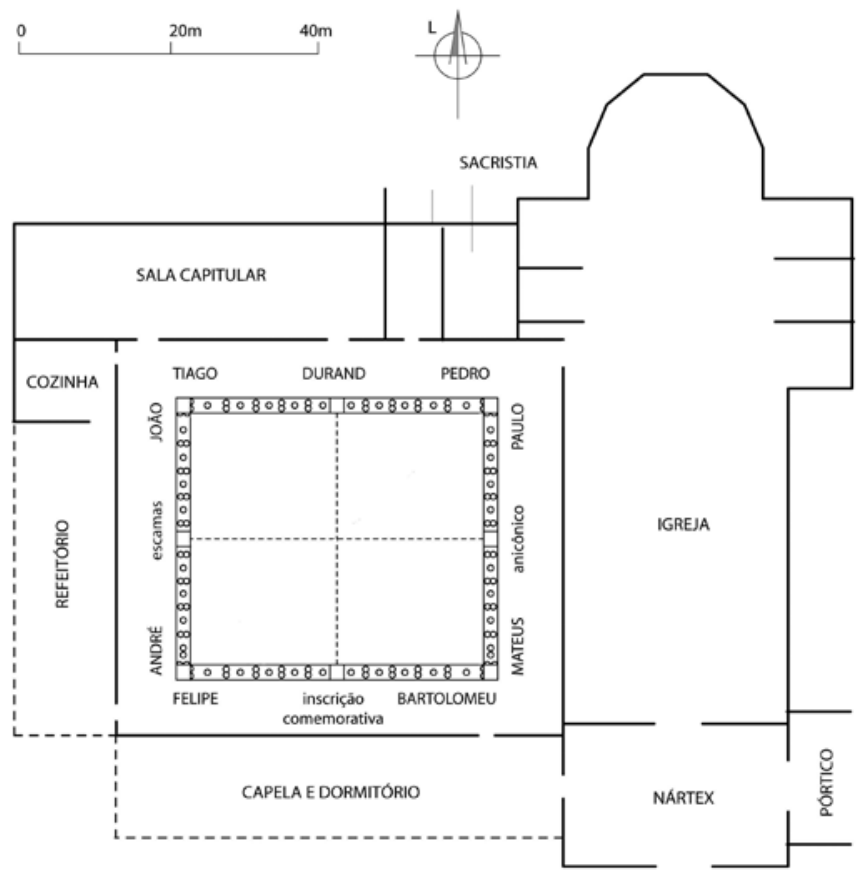

Fig. 1 - Esquema do claustro. Maria Cristina C. L. Pereira e Melissa Guizzardi, a partir de SCHAPIRO, Meyer. The sculpture of Moissac. Londres: Thames and Hudson, 1985, p. 2.

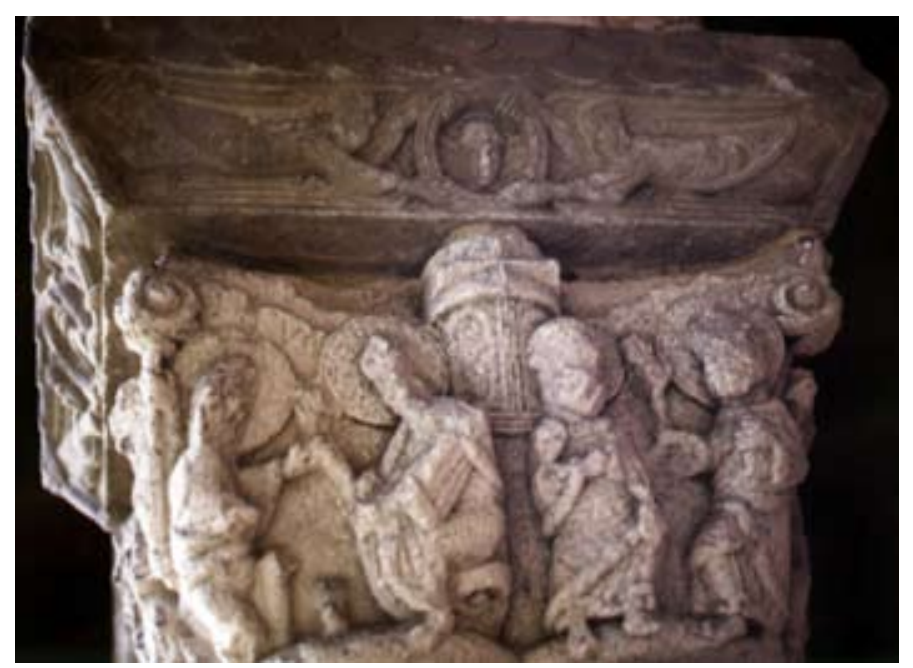

Fig. 3 - Capitel do lava-pés, face sul, galeria leste, claustro de Moissac. Fotografia: Maria Cristina C. L. Pereira. 


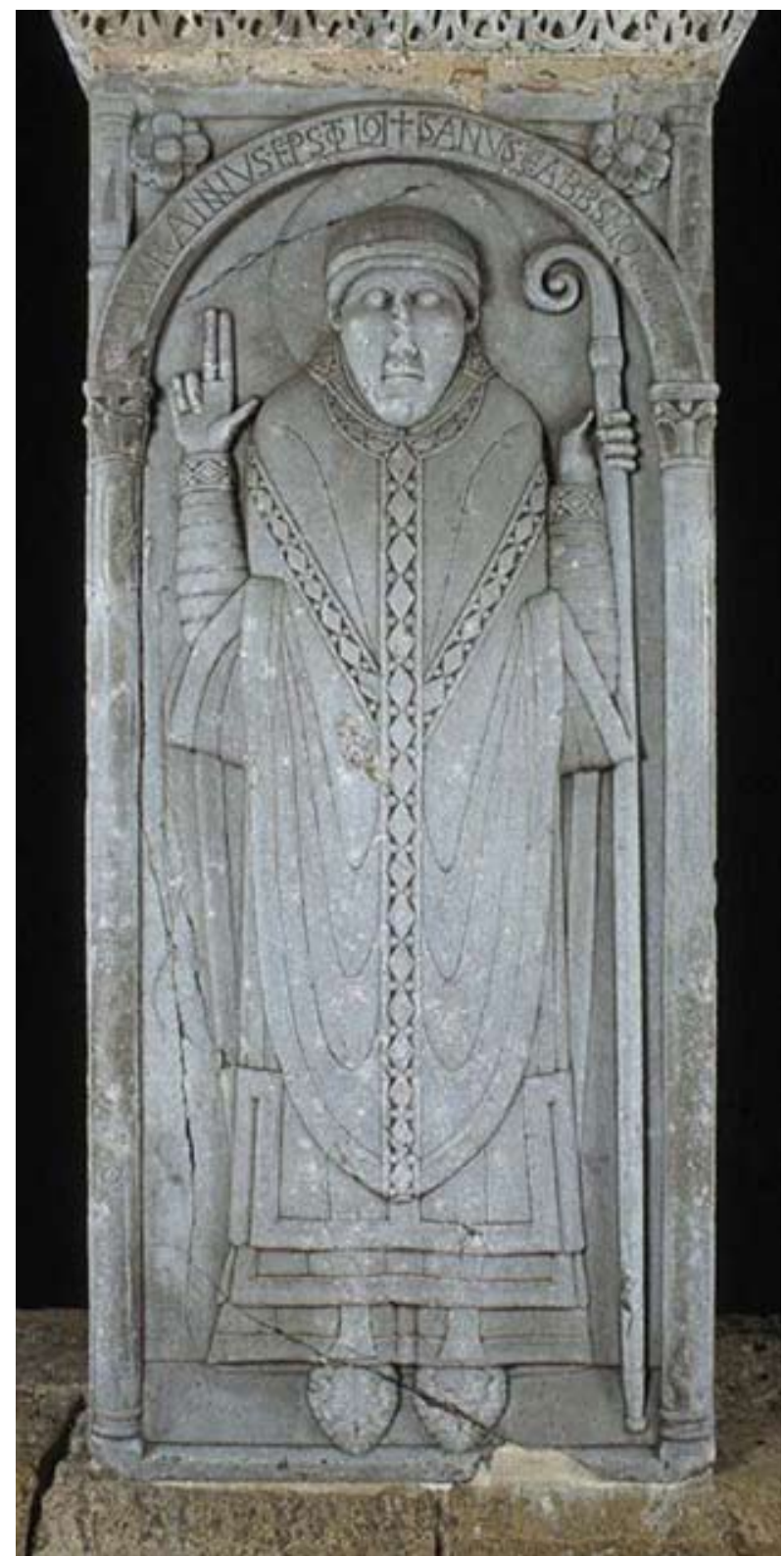

Fig. 2 - Relevo de Durand, galeria leste, claustro de Moissac. Fotografia: Guy-Marie Renié. In: CAZES, Quitterie; SCÈLLES, Maurice. Le cloître de Moissac. Bordeaux: Sud-Ouest, 2001, p. 164. 


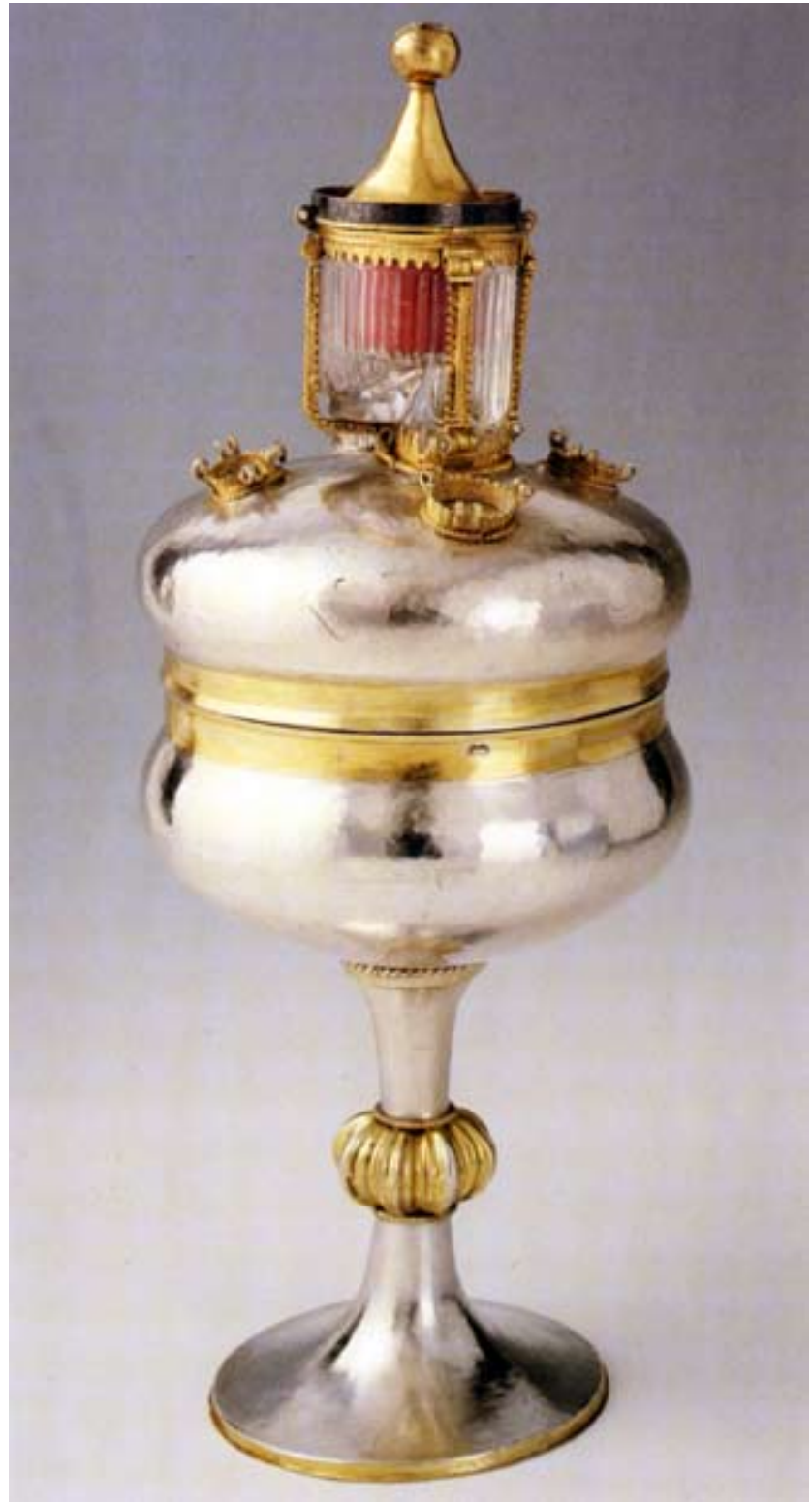

Fig. 1 - Cibório relicário com peça de xadrez em cristal, séculos X-XIII (?). Münster, Domkammer. In: JÁSZAI, Géza. Die Domkammer der Kathedralkirche Sankt Paulus in Münster. Kommentare zu ihrer Bilderwelt. Münster: Kapitel, 1991, p. 16. 
Philippe CORDEZ. Caderno de Imagens.

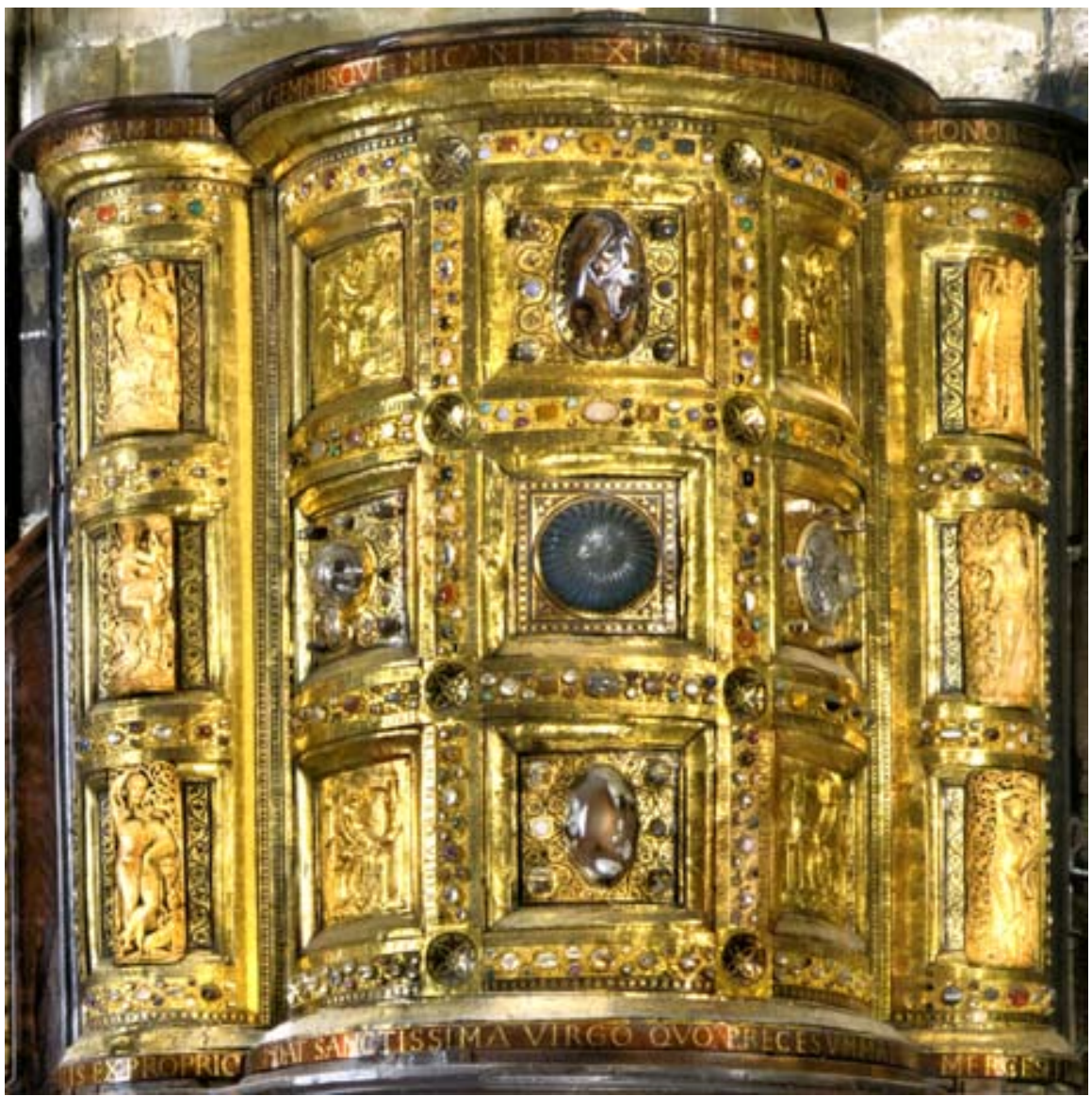

Fig. 2 -Ambão ofertado por Henrique II, 1002-1007 (?), com vinte e sete peças de xadrez. Aix-la-Chapelle, Domschatzkammer. In: REUDENBACH, Bruno (org.). Karolingische und ottonische Kunst. Munique: Prestel, 2009, p. 69. 


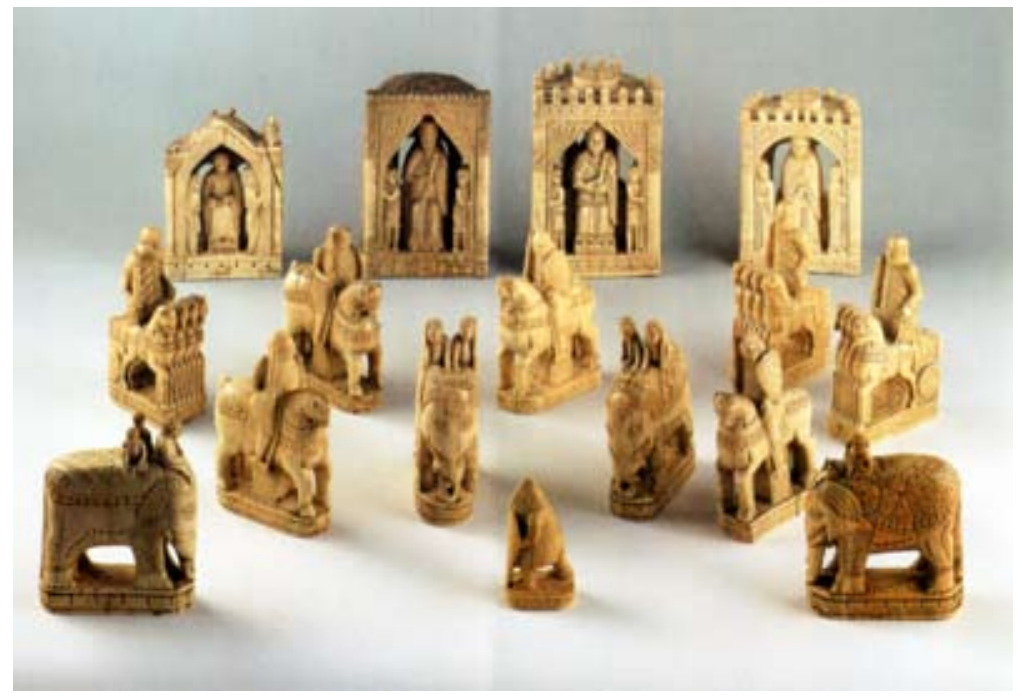

Fig. 3 - Dezesseis peças de xadrez em marfim, Itália do Sul, fim do século XI (?). Desde 1124-1129 (?) na abadia de Saint-Denis com o nome de "xadrez de Carlos Magno". Paris, Bibliothèque nationale de France, Département des monnaies, médailles et antiques. In: PASTOUREAU, Michel. L'échiquier de Charlemagne: un jeu pour ne pas jouer. Paris: Adam Biro, 1990.

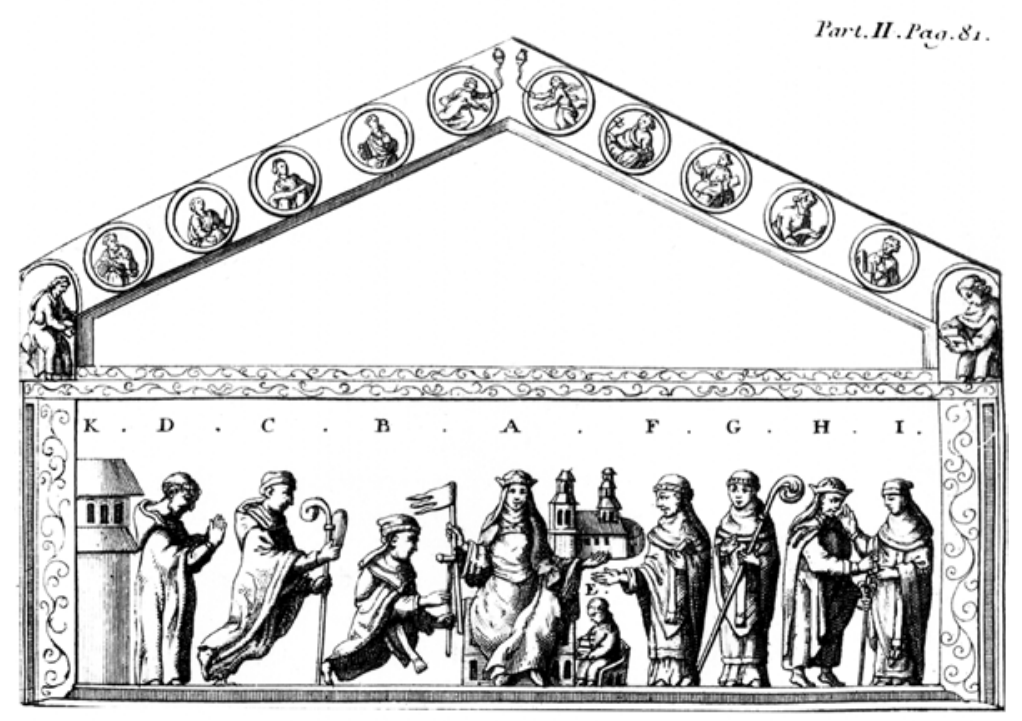

Fig. 5 - Fastigium ou monumento de pedra enquadrando trono real, anos 1130 (?). Reims, abadia de Saint-Rémi. In: MARTÈNE, Edmond; DURAND, Ursin. Voyage littéraire de deux religieux bénédictins de la congrégation de Saint-Maur. 2 t. Paris: Delaulne et Montalant, 1717-1724, t. 2, p. 81. 
Philippe CORDEZ. Caderno de Imagens.
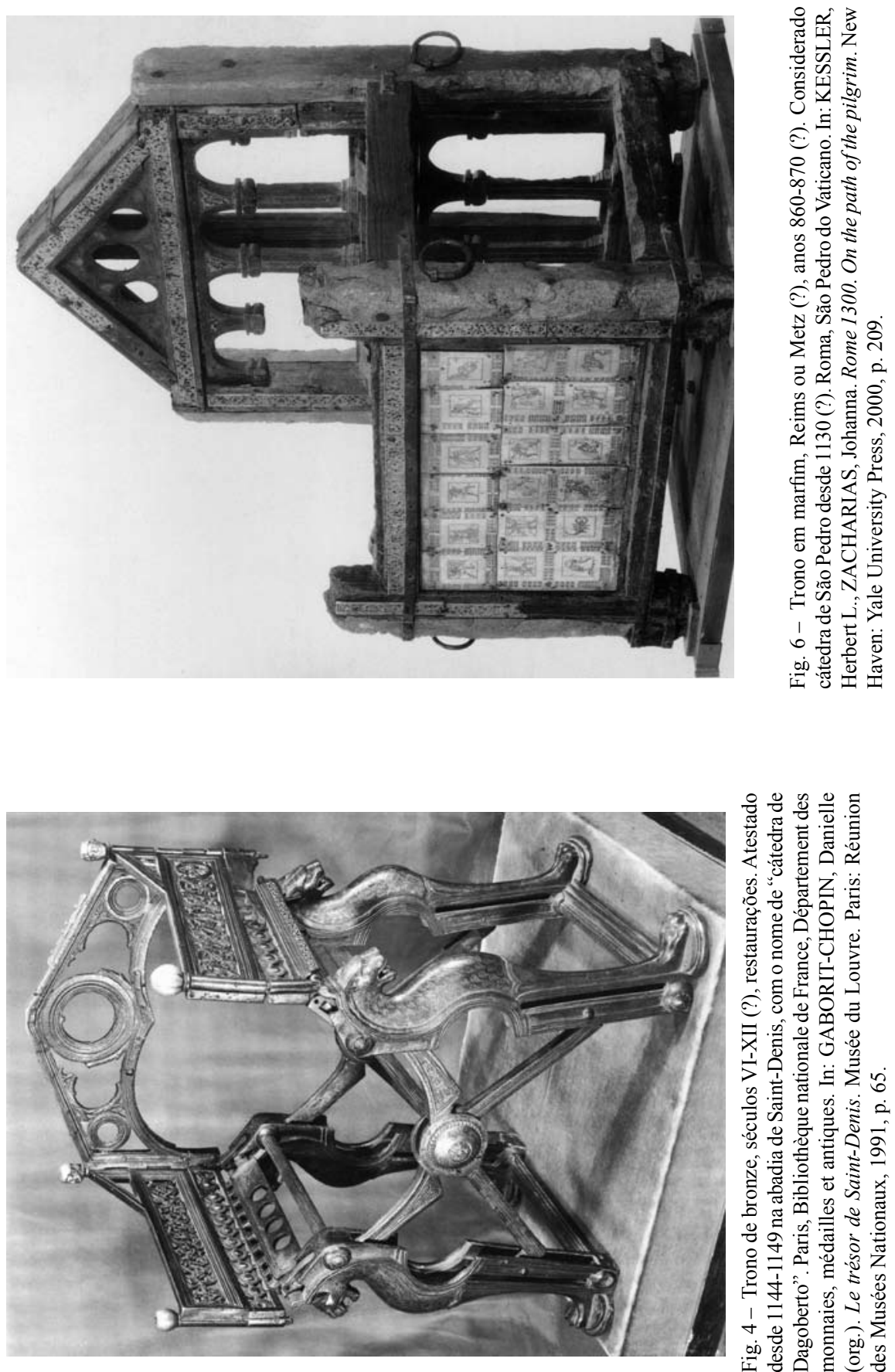


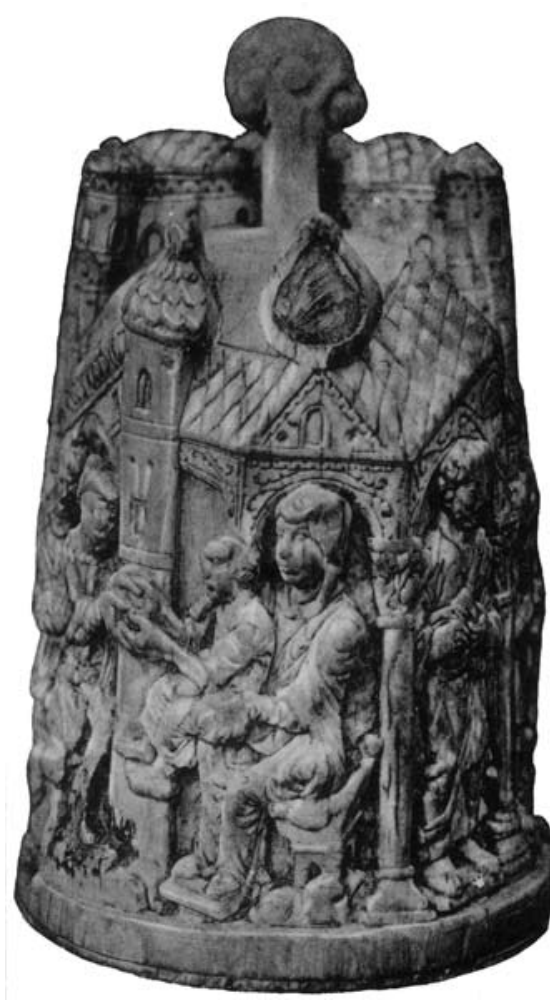

Fig. 7-10 - Objeto de marfim em forma de rei do xadrez ornado com imagens. Proveniente de Reims, c. 1130 (?). Paris, Musée national du Moyen Âge - Thermes et hôtel de Cluny. In: GOLDSCHMIDT, Adolph. Die Elfenbeinskulpturen aus der Zeit der Karolingischen und Sächsischen Kaiser. VIII.-XI. Jahrhundert. 2 t. Berlim: Deutscher Verlag für Kunstwissenschaft, 1914$1918 ; 1969-1970$, t. 2, prancha XL.

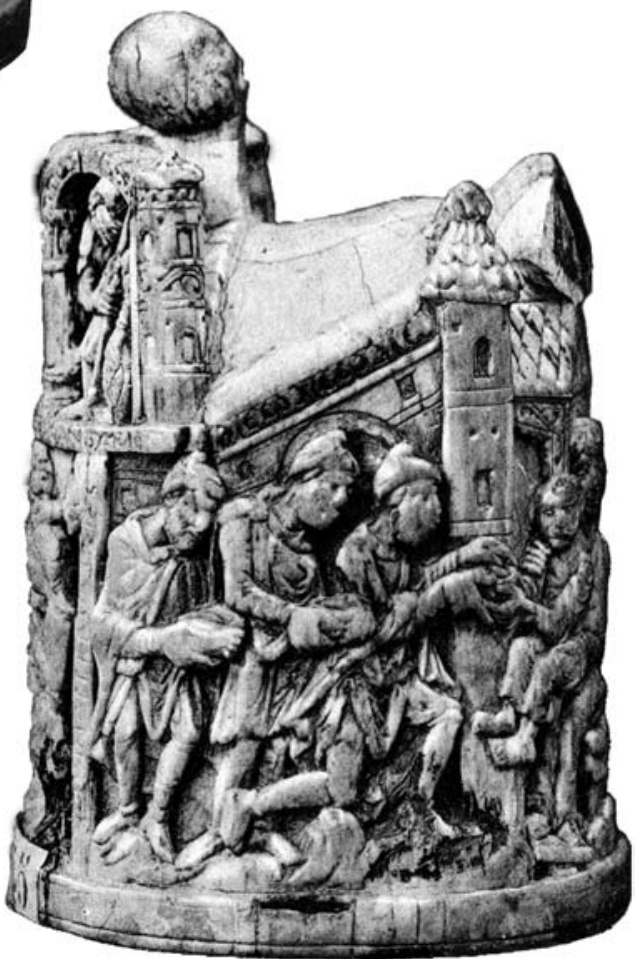


Philippe CORDEZ. Caderno de Imagens.

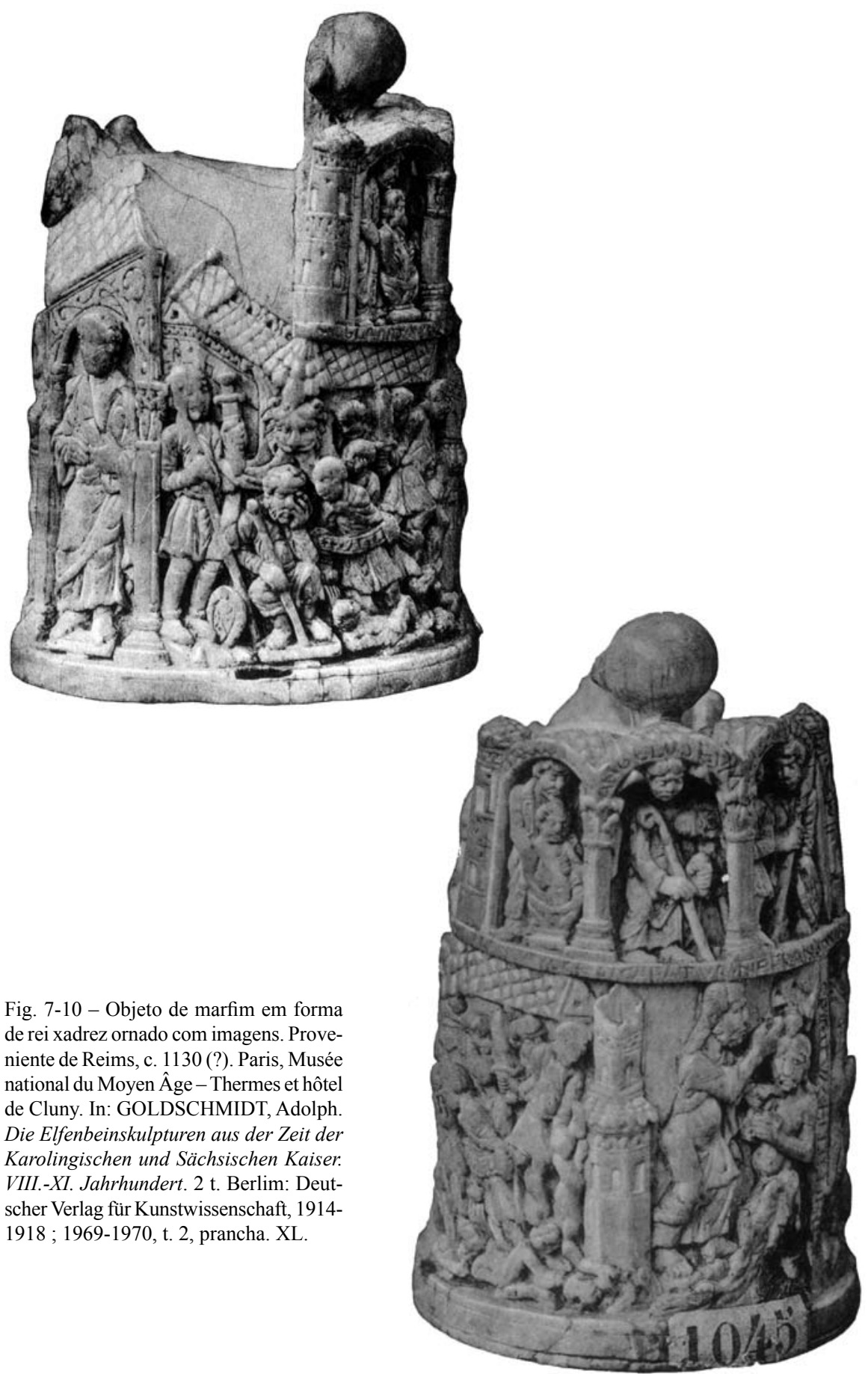


Elisa BRILLI. As formas da história. Caderno de Imagens.

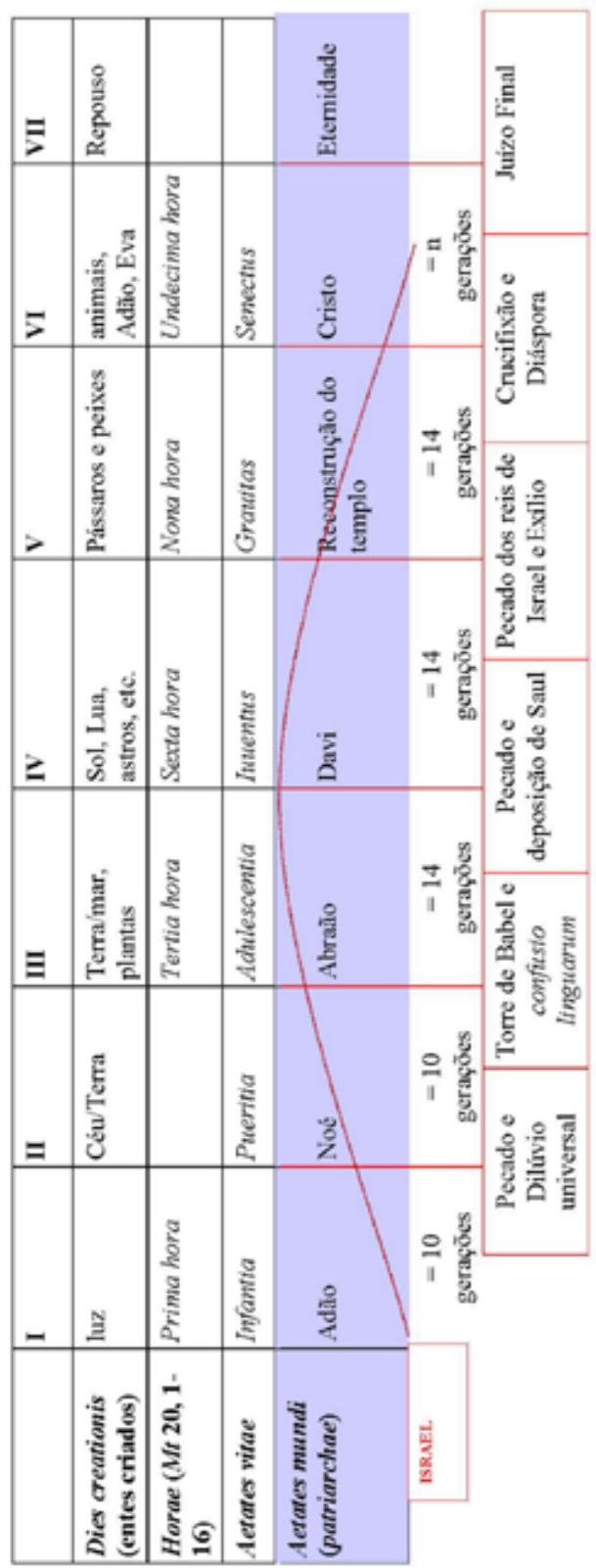

苞 
Elisa BRILLI. As formas da história. Caderno de Imagens.

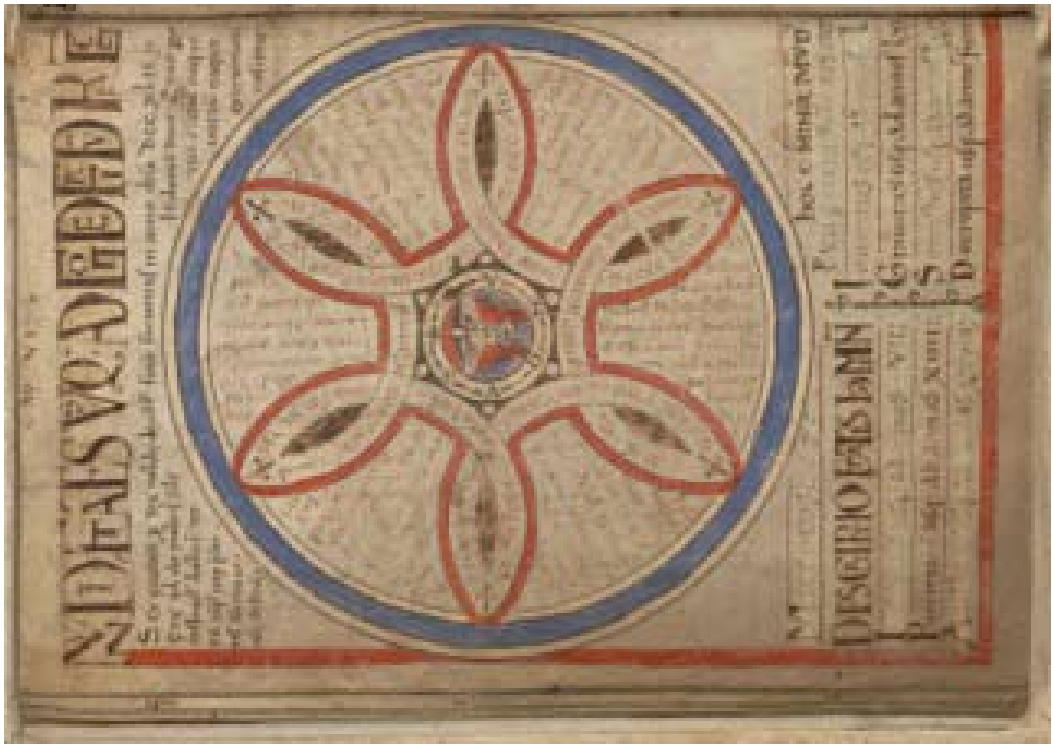

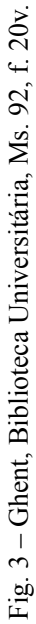

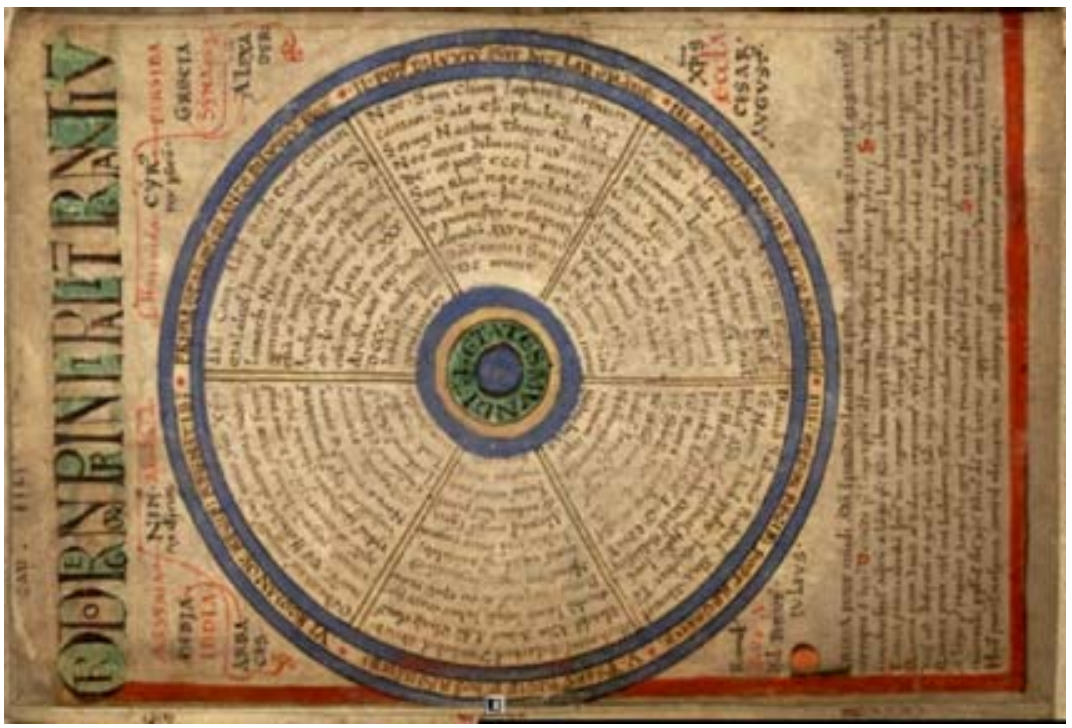

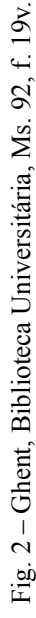


Elisa BRILLI. As formas da história. Caderno de Imagens.
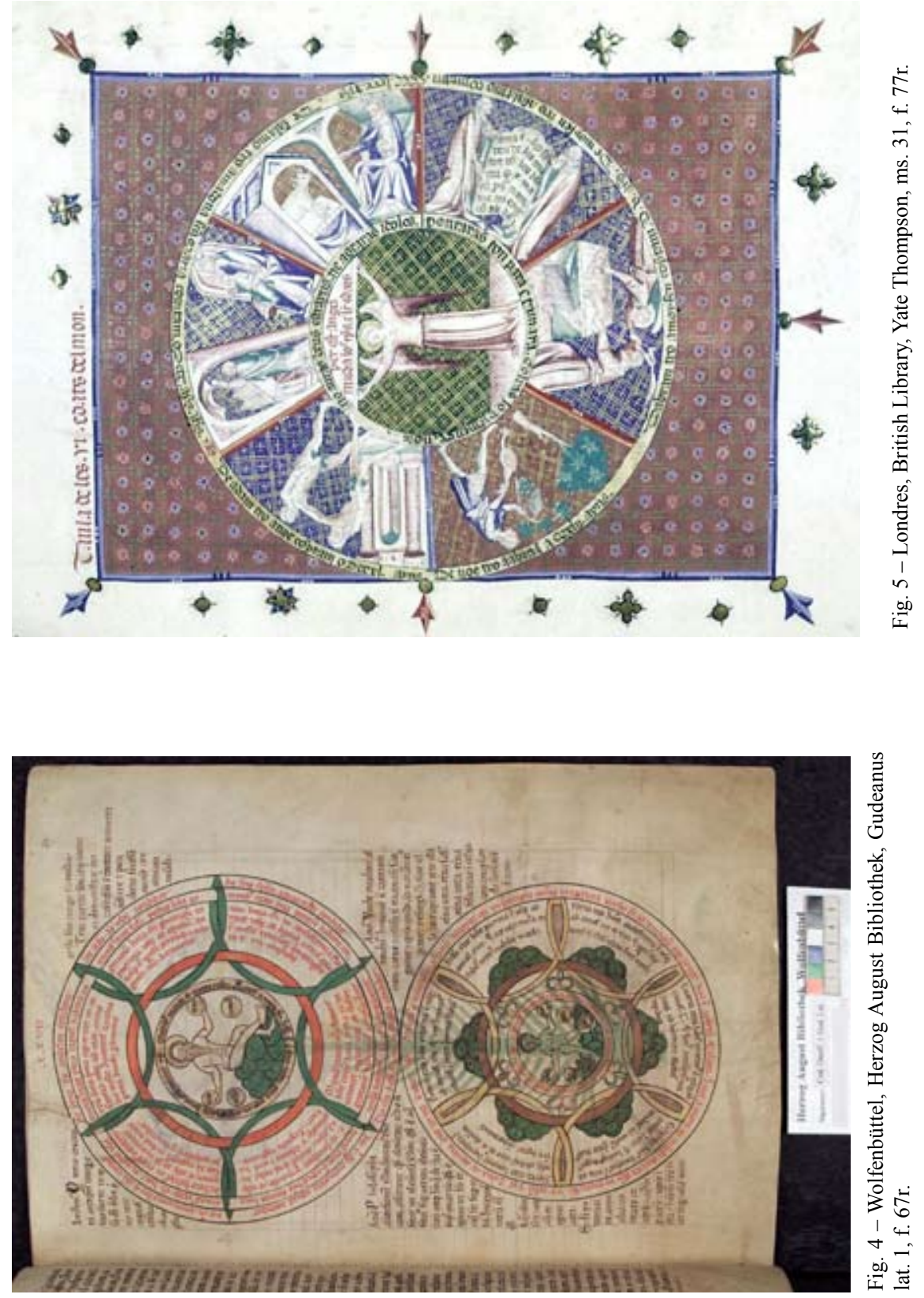

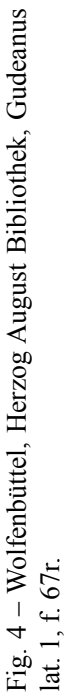


Elisa BRILLI. As formas da história. Caderno de Imagens.

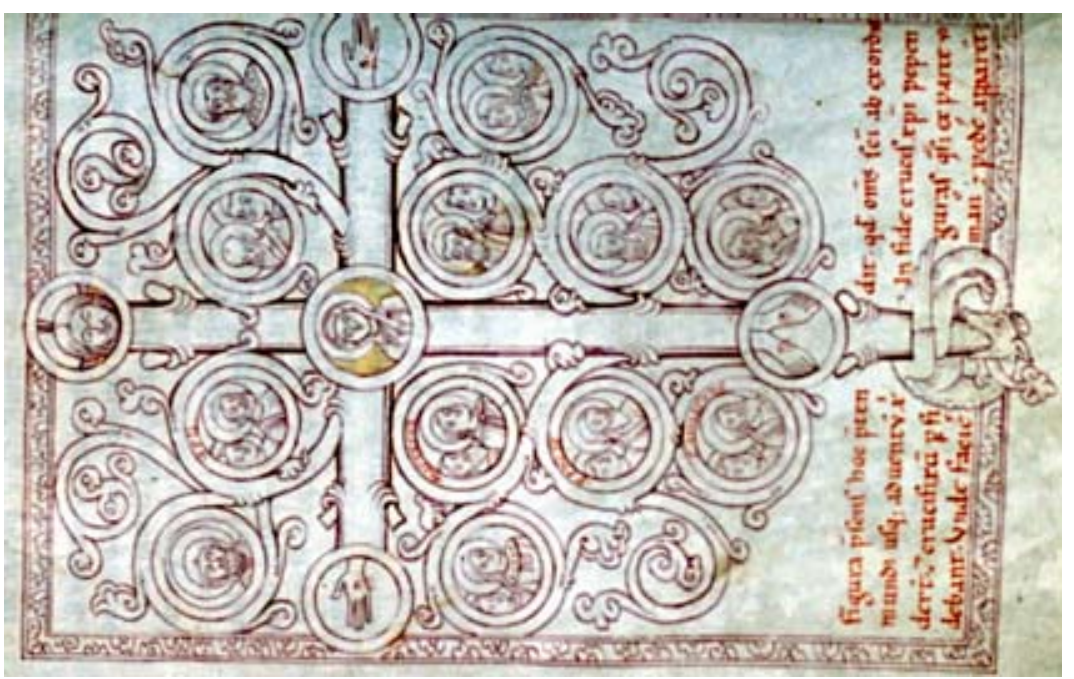

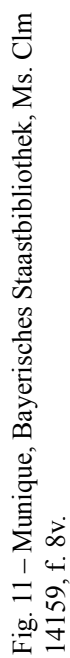

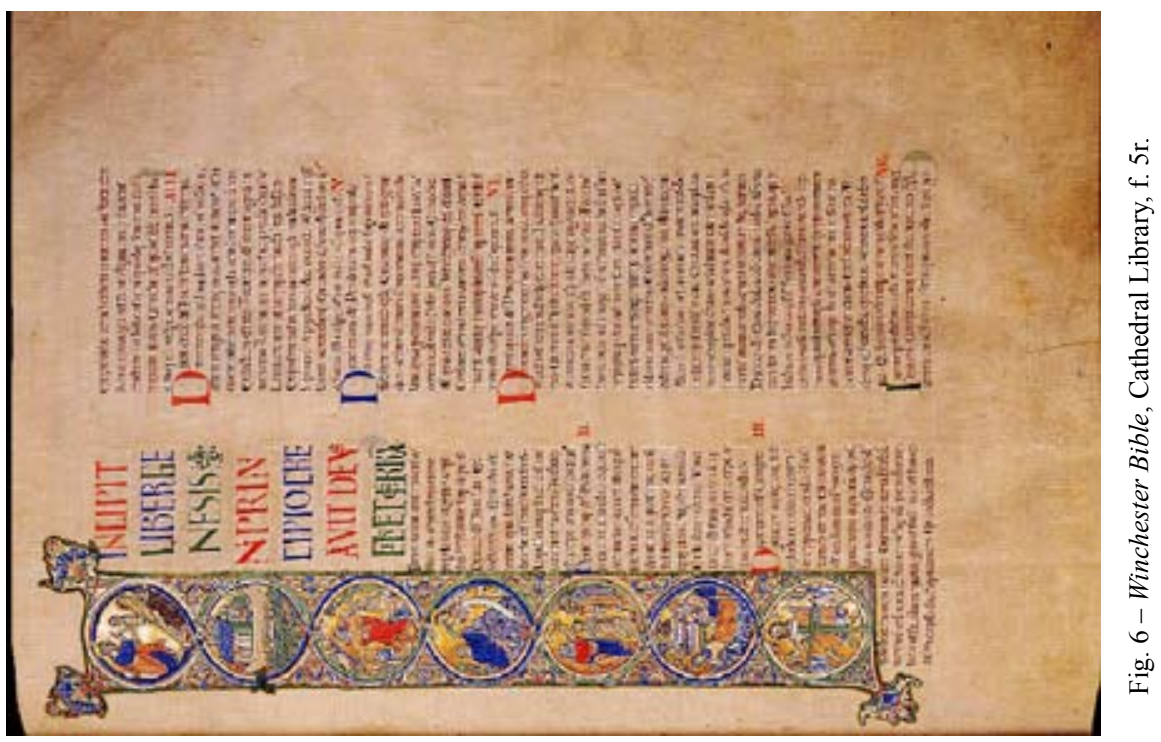


Elisa BRILLI. As formas da história. Caderno de Imagens.

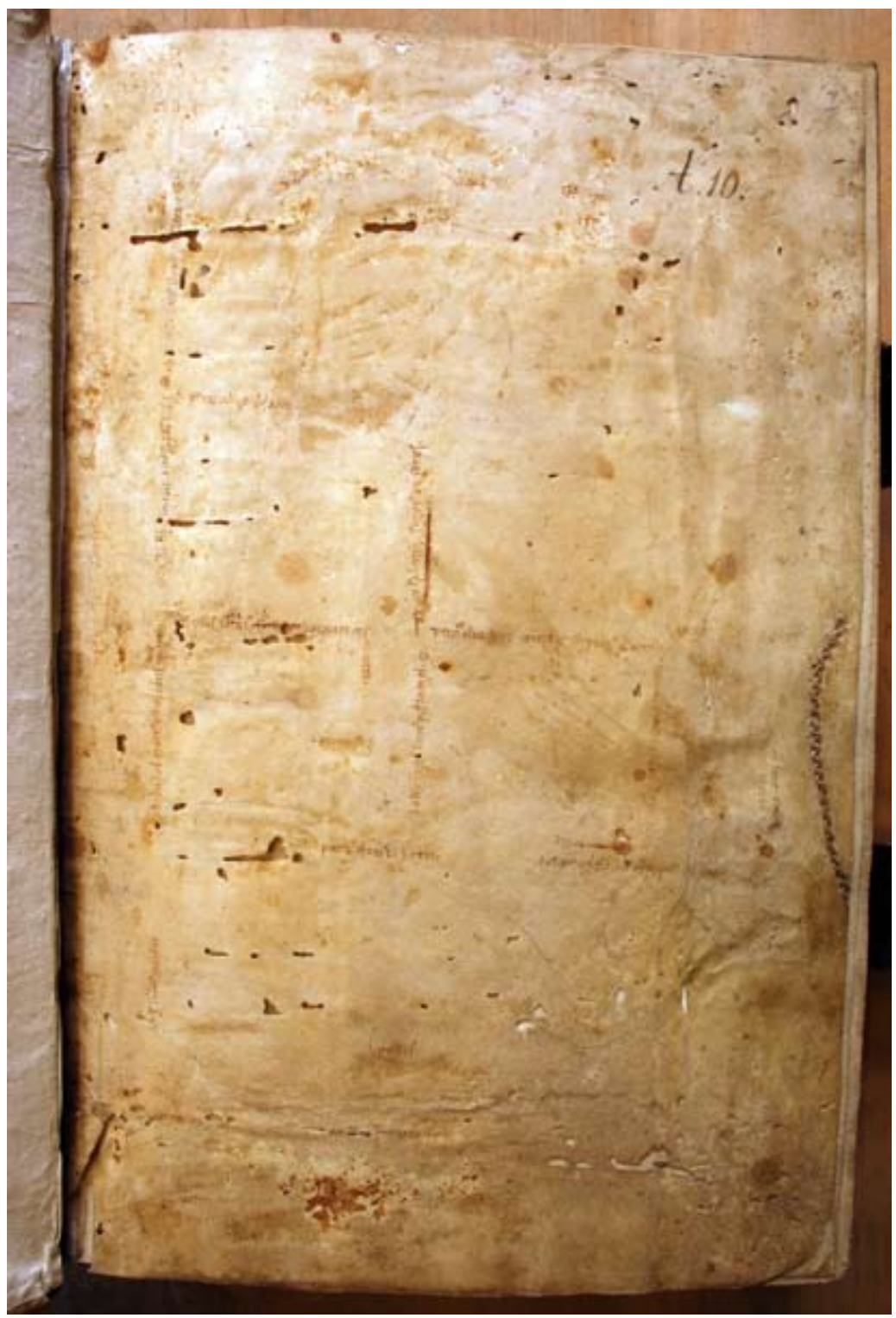

Fig. 7 - Pforta, Bibliothek der KGL. Landes-Schule, Ms. Lat. A. 10, f. IIr. 
Elisa BRILLI. As formas da história. Caderno de Imagens.

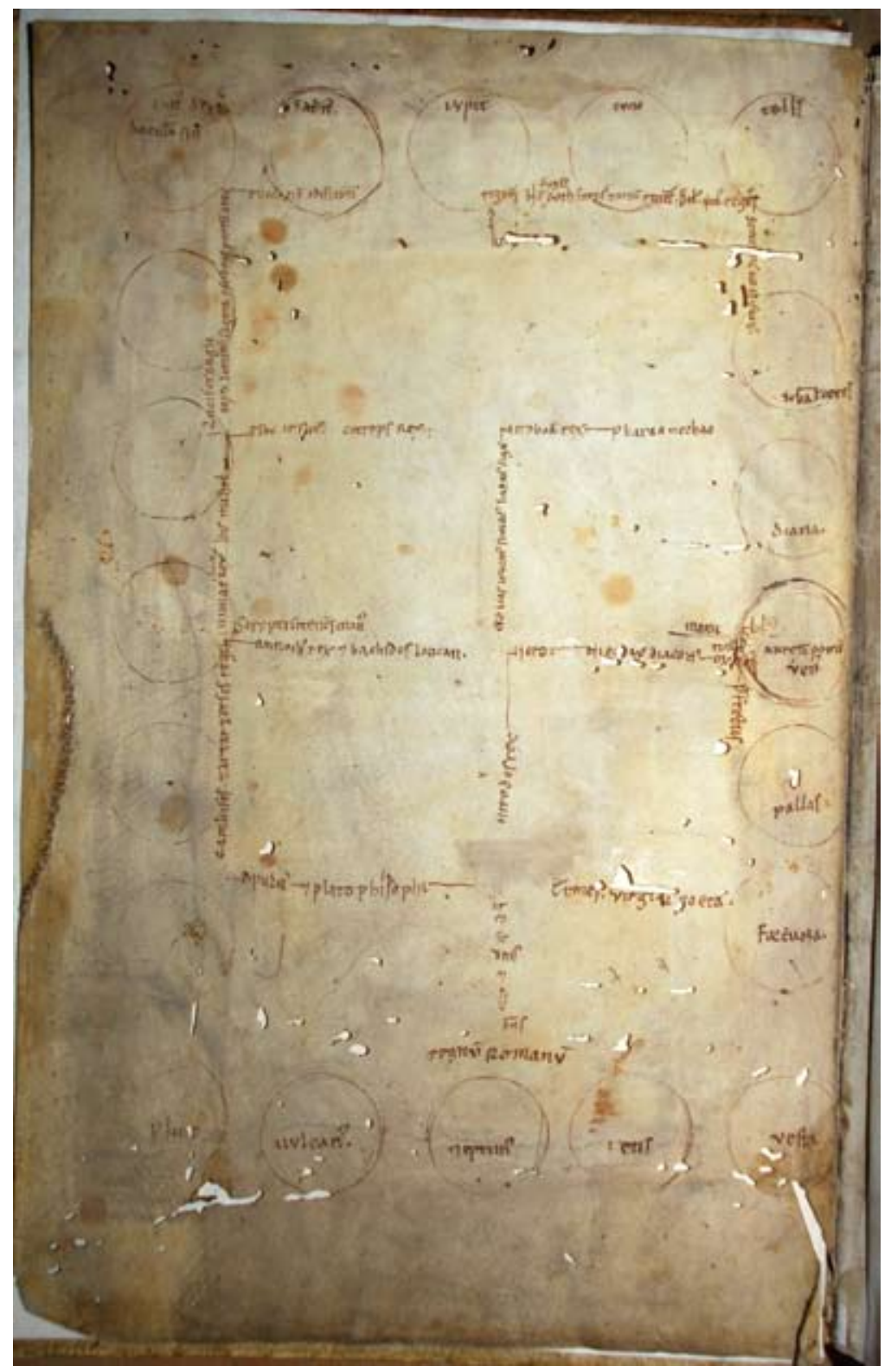

Fig. 8 - Pforta, Bibliothek der KGL. Landes-Schule, Ms. Lat. A. 10, f. IIv. 


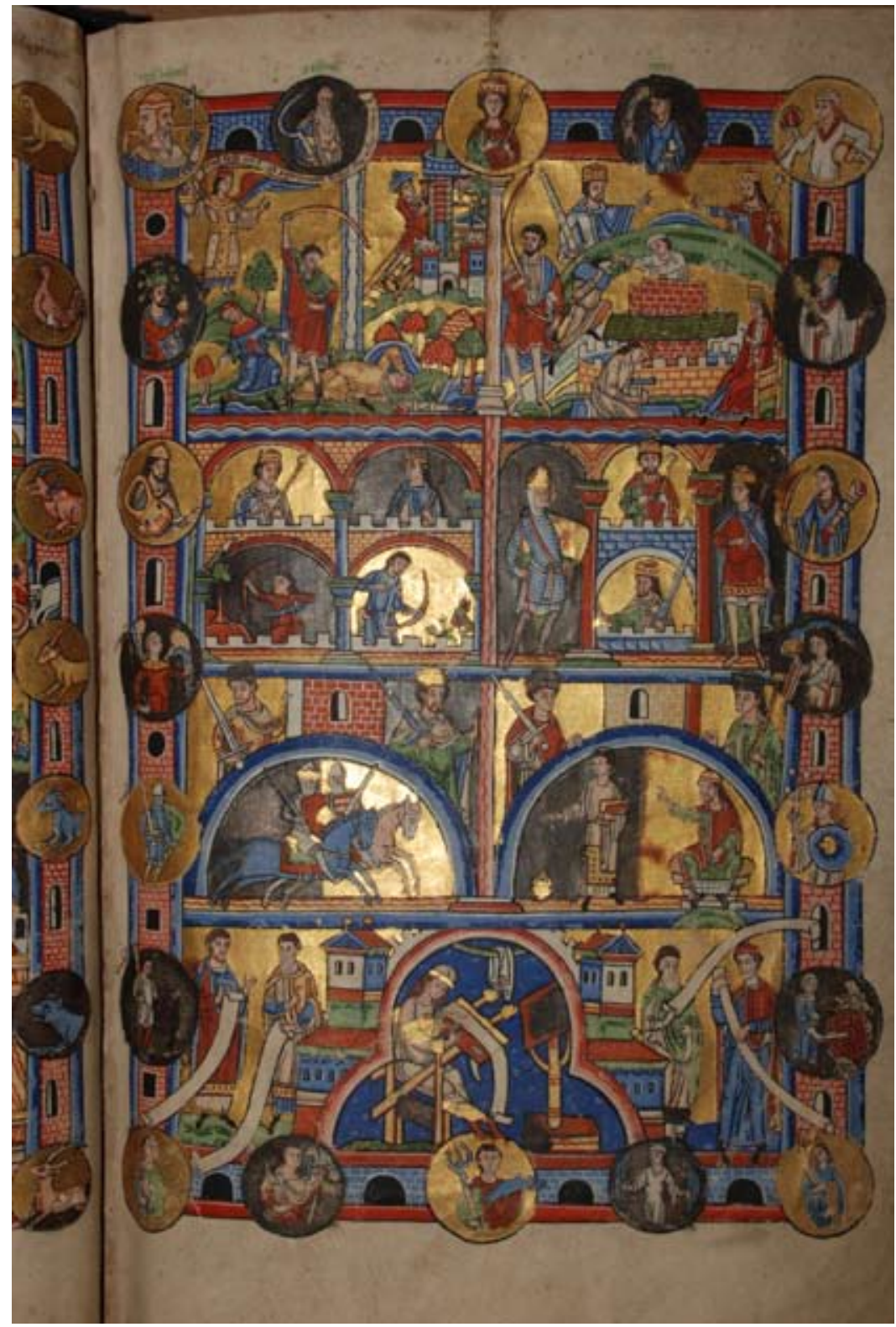

Fig. 9 - Pforta, Bibliothek der KGL. Landes-Schule, Ms. Lat. A. 10, f. 3r. 
Elisa BRILLI. As formas da história. Caderno de Imagens.

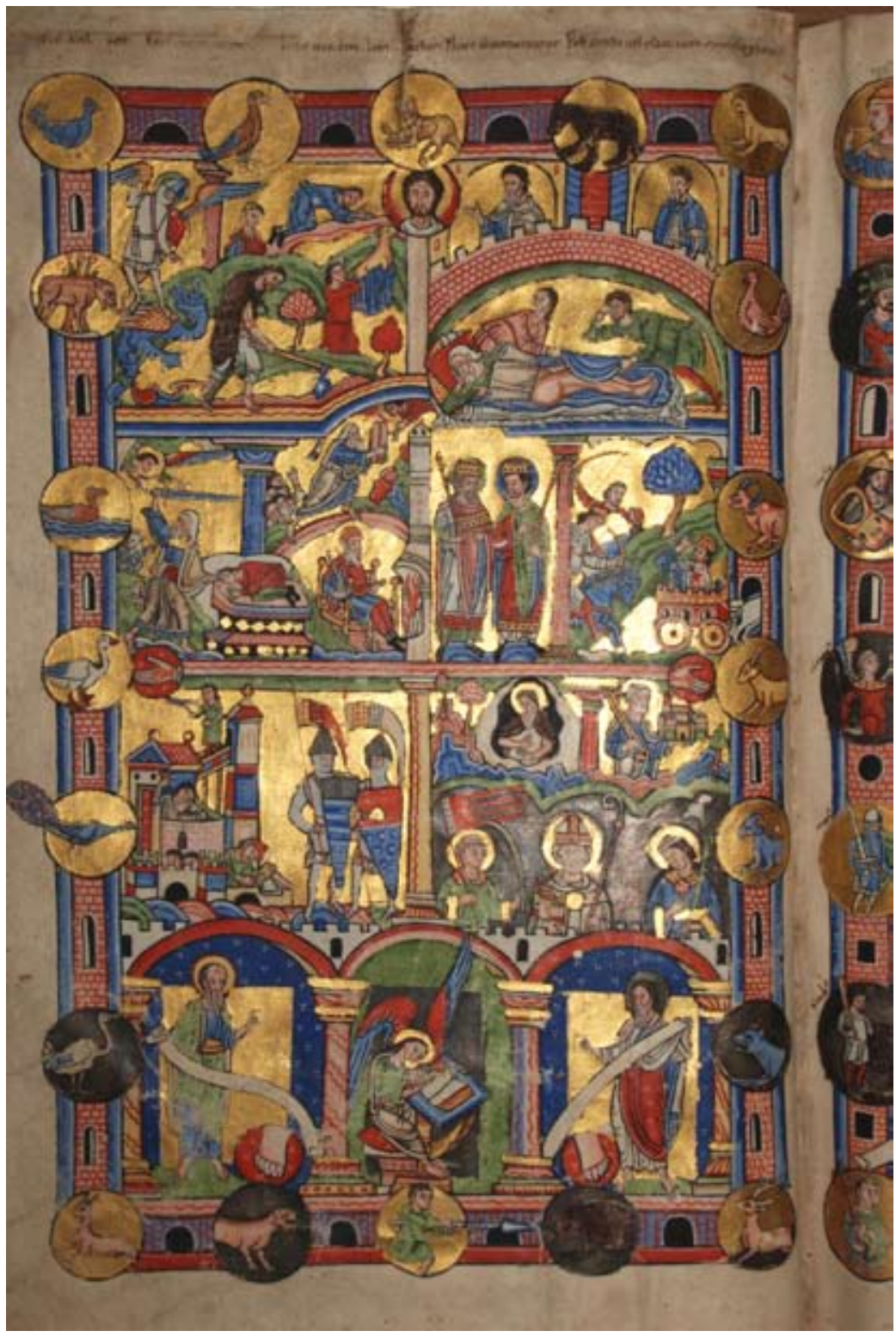

Fig. 10 - Pforta, Bibliothek der KGL. Landes-Schule, Ms. Lat. A. 10, f. 2v. 


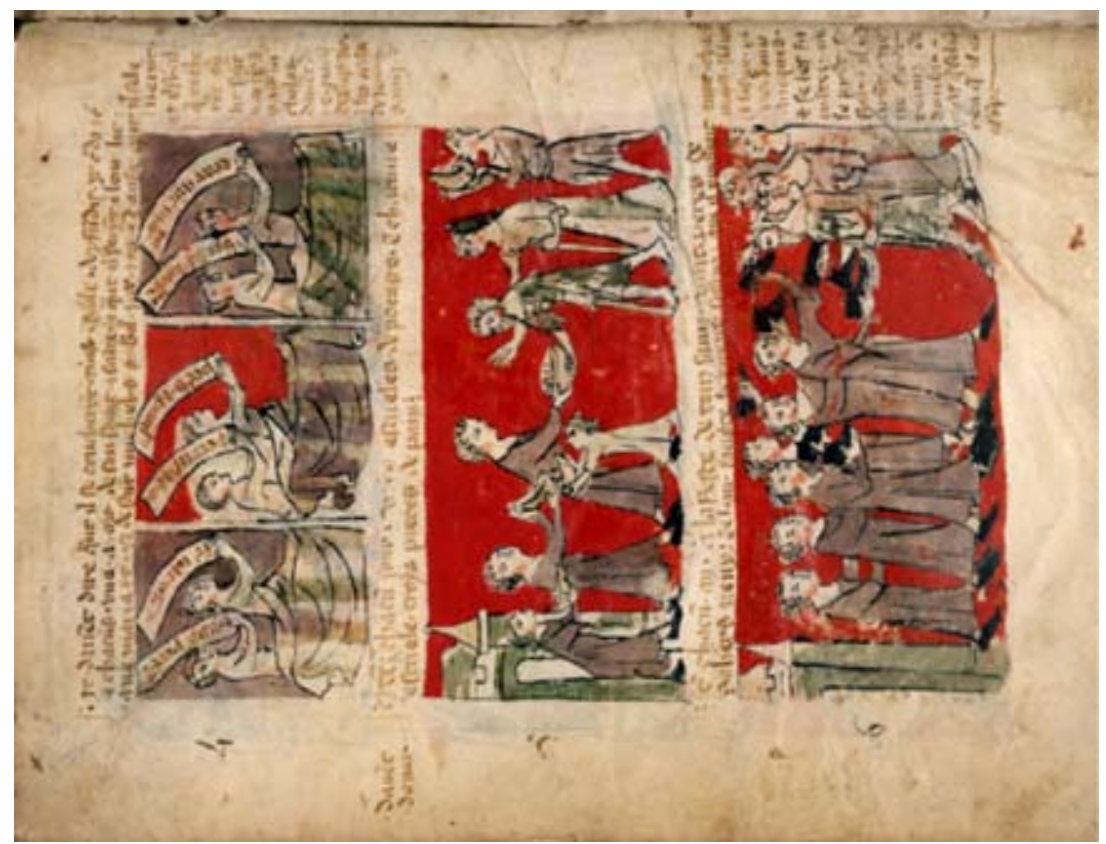

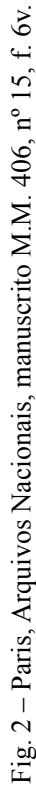

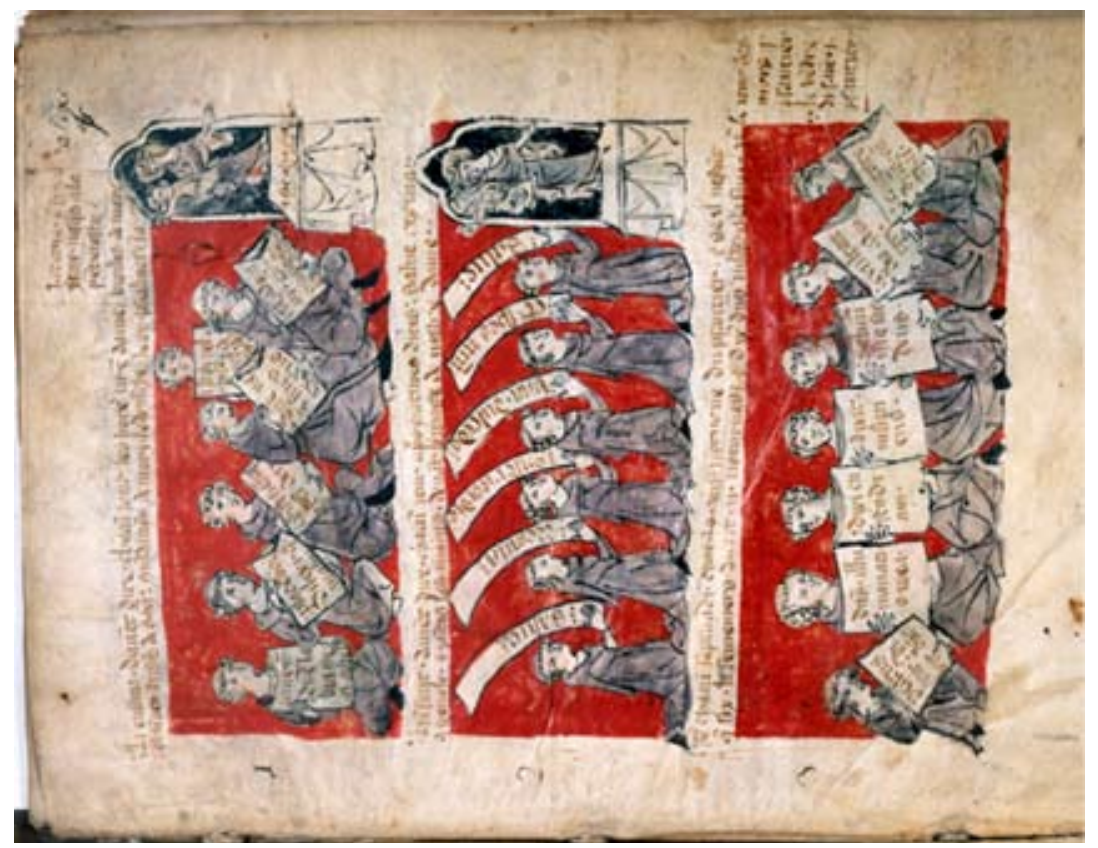

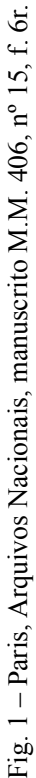




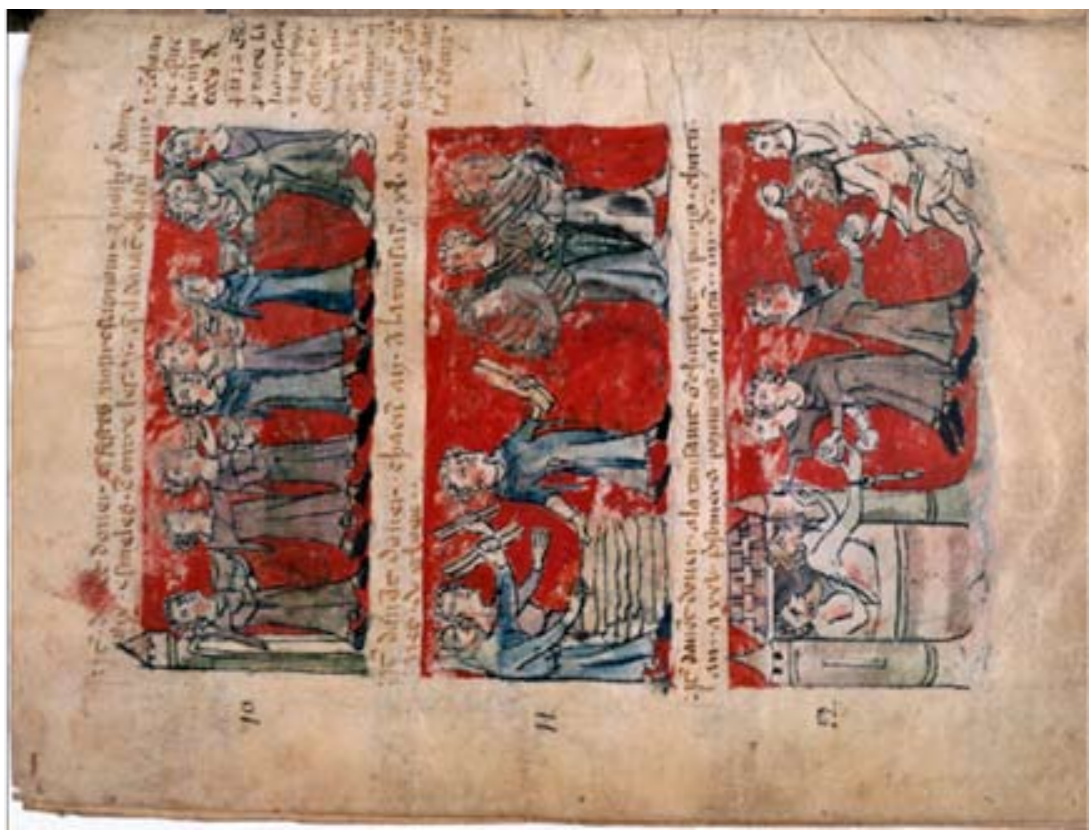

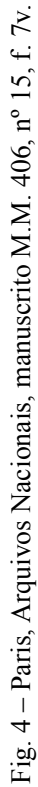

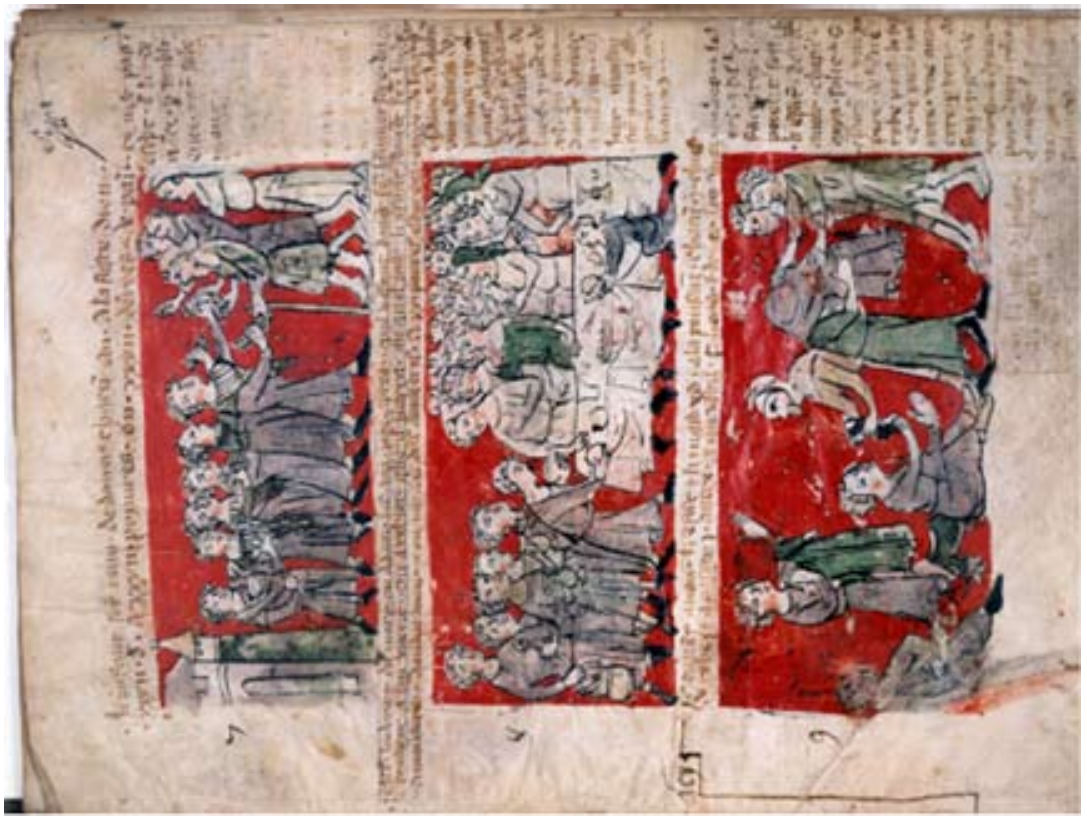

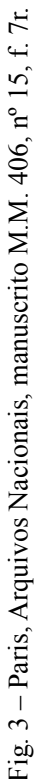


Eduardo Henrik AUBERT. Caderno de Imagens.

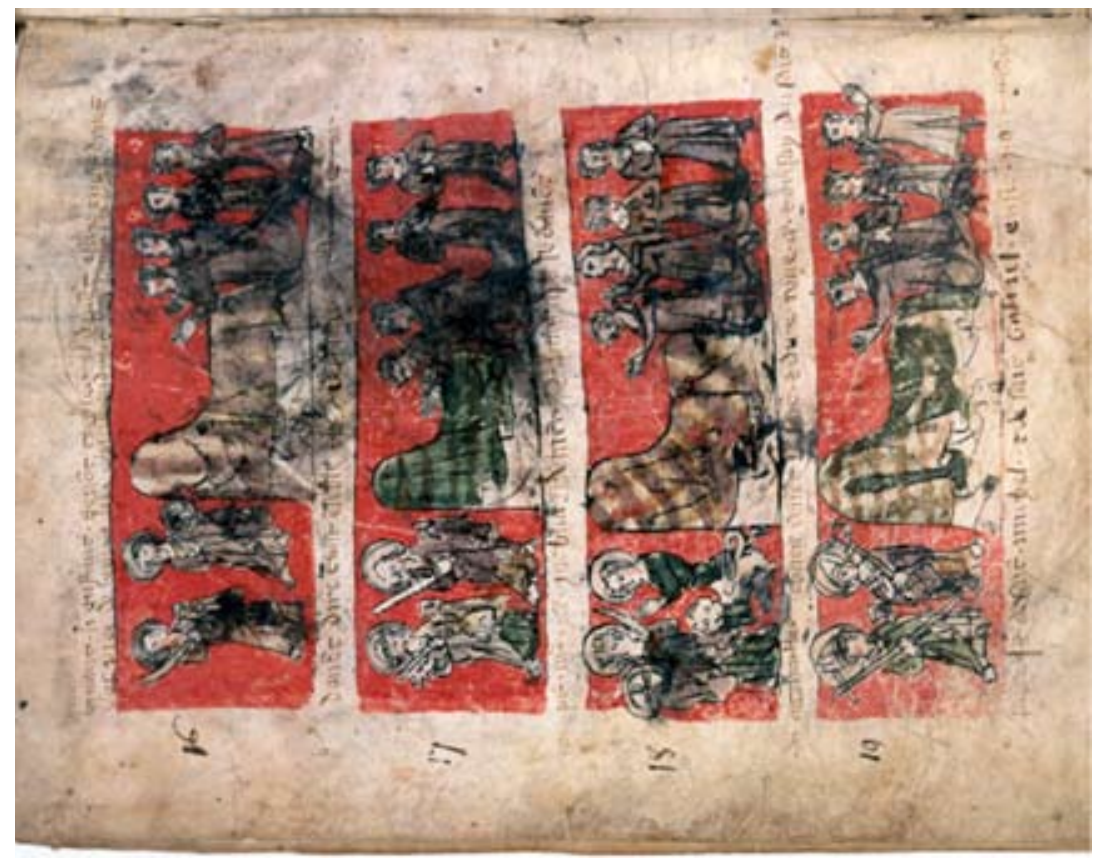

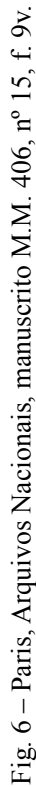

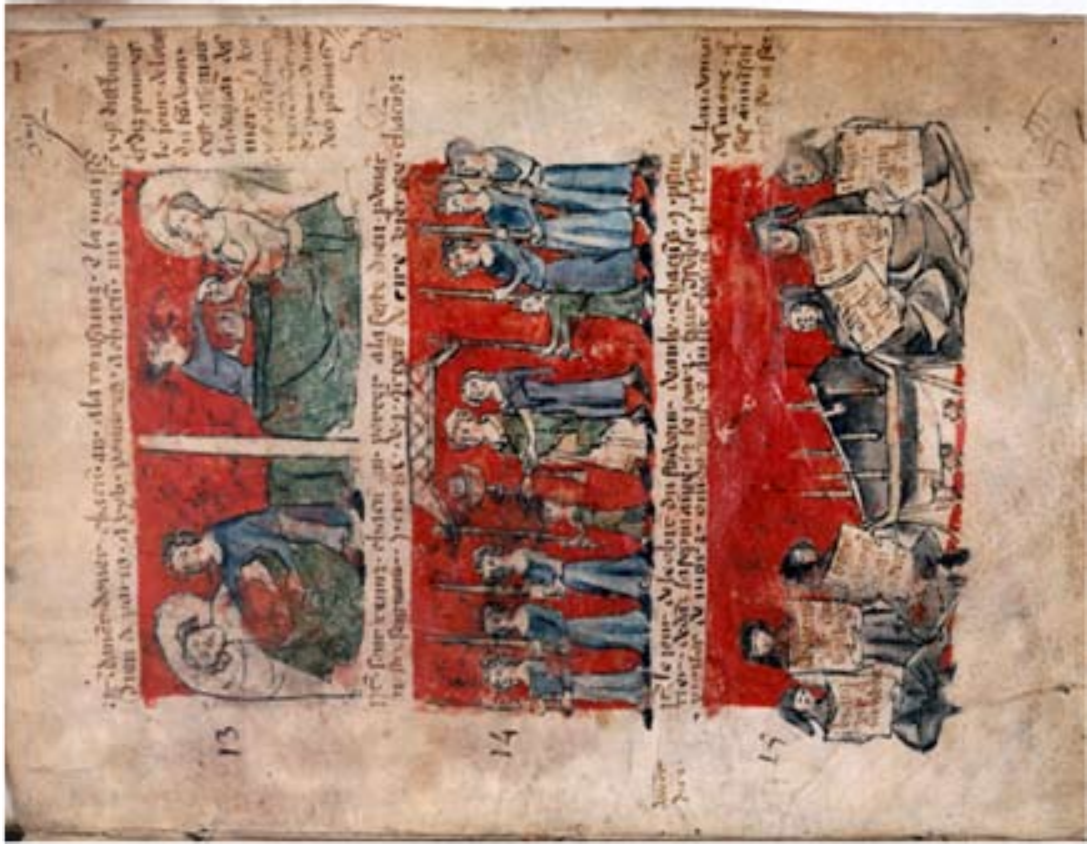

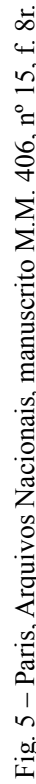



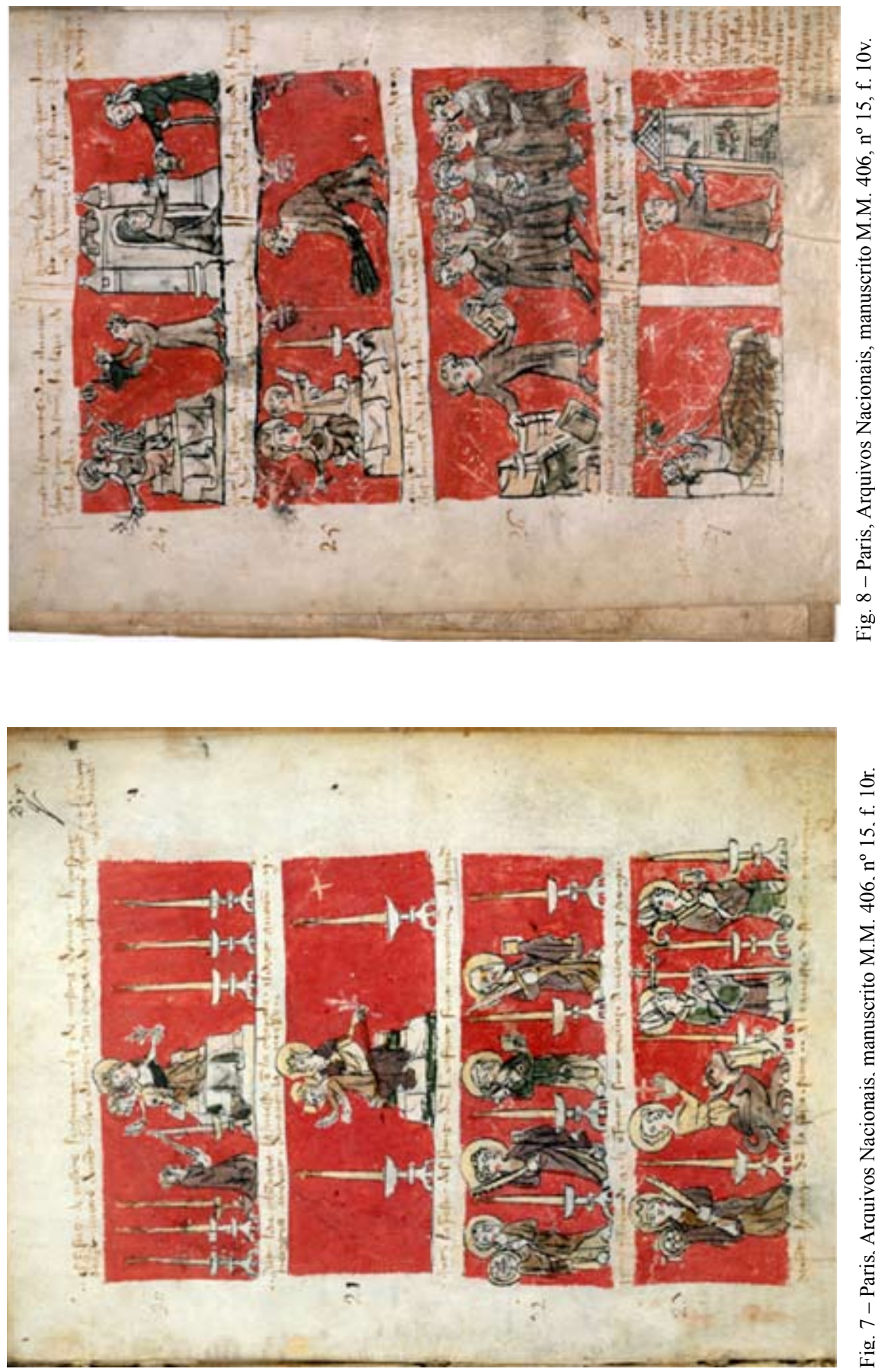

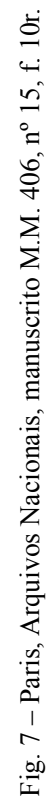


Eduardo Henrik AUBERT. Caderno de Imagens.

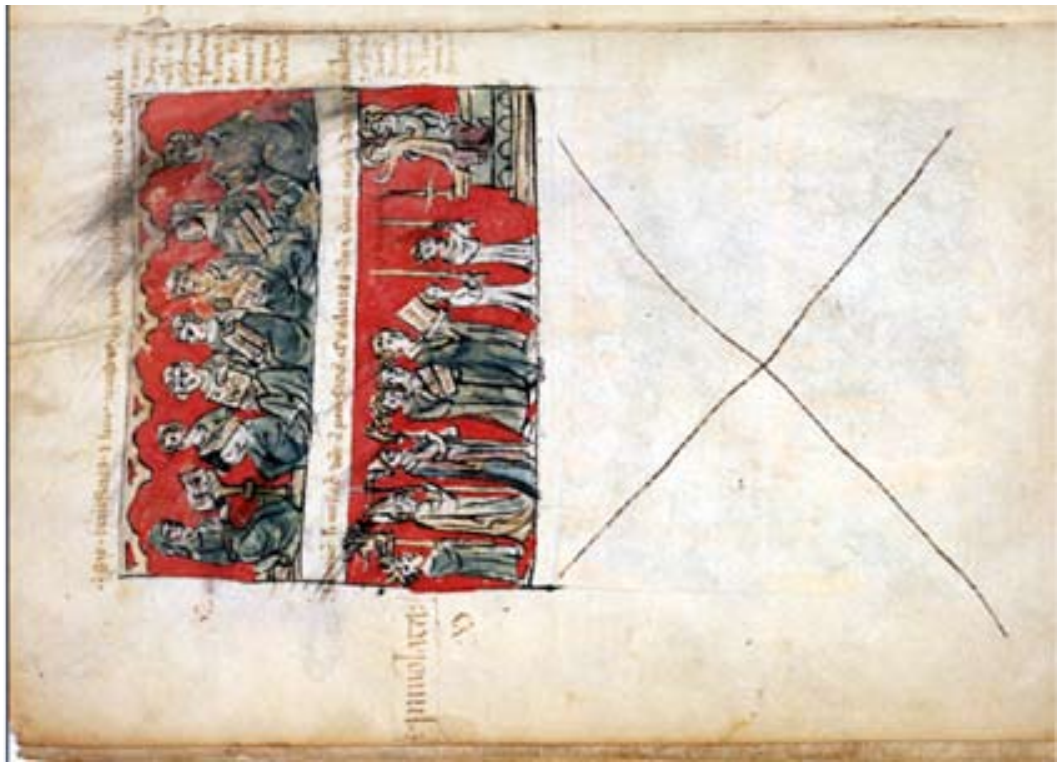

ב

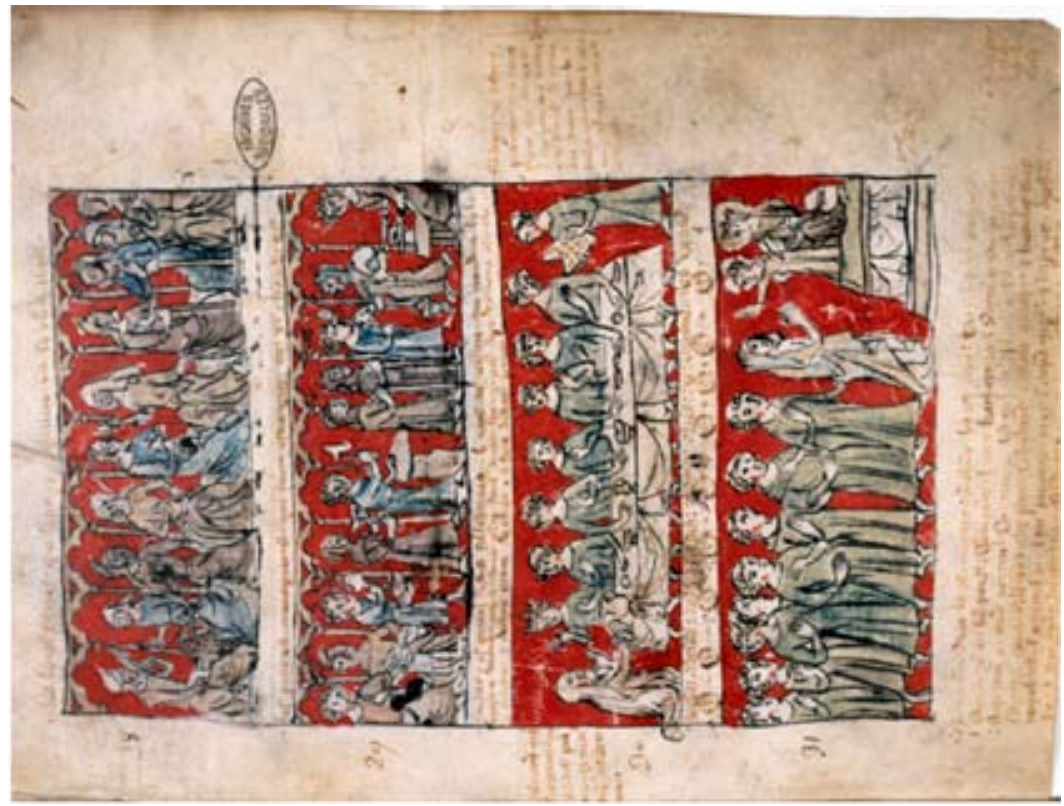

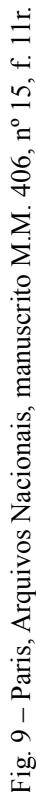



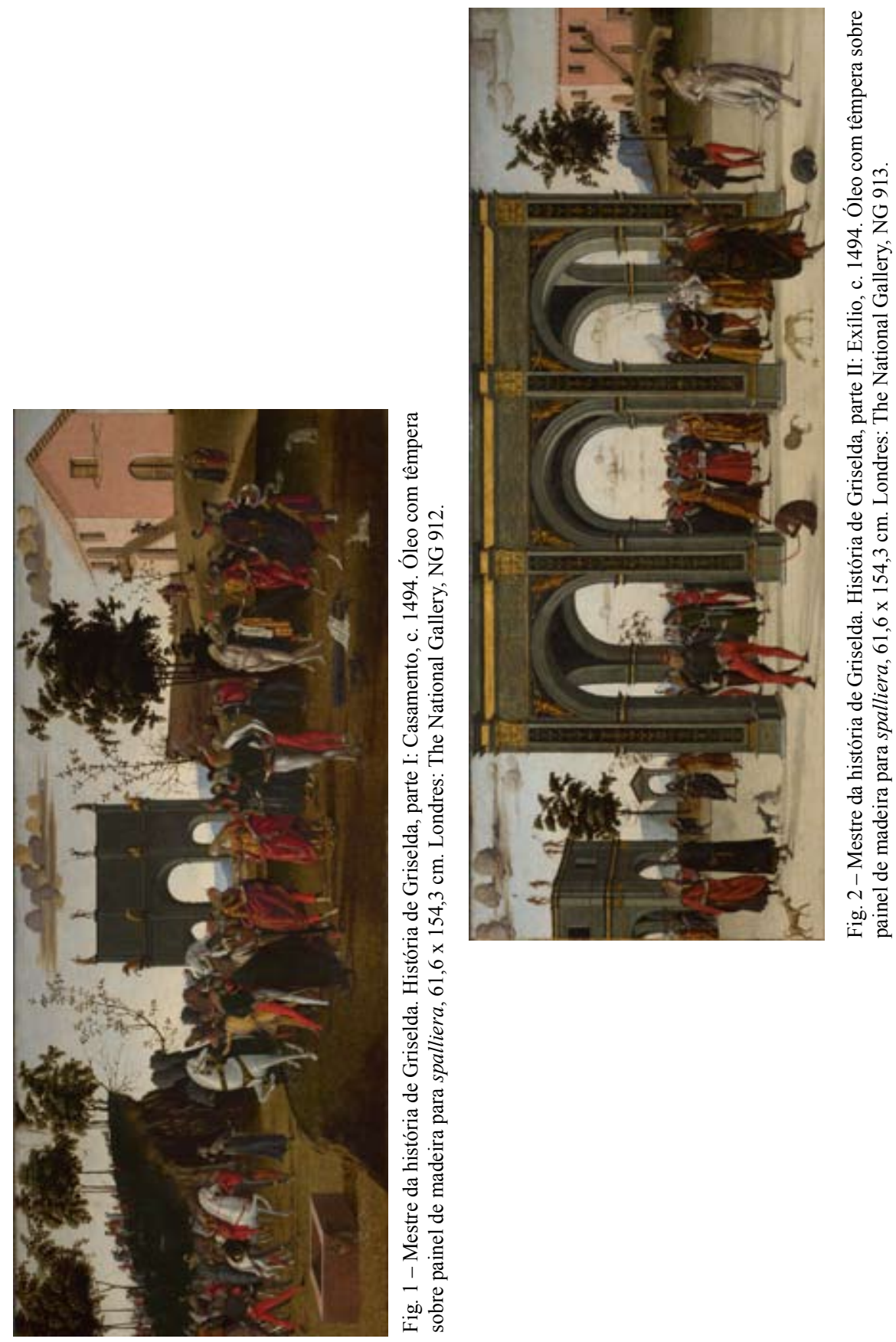
Diogo Rodrigues de BARROS. Caderno de Imagens.
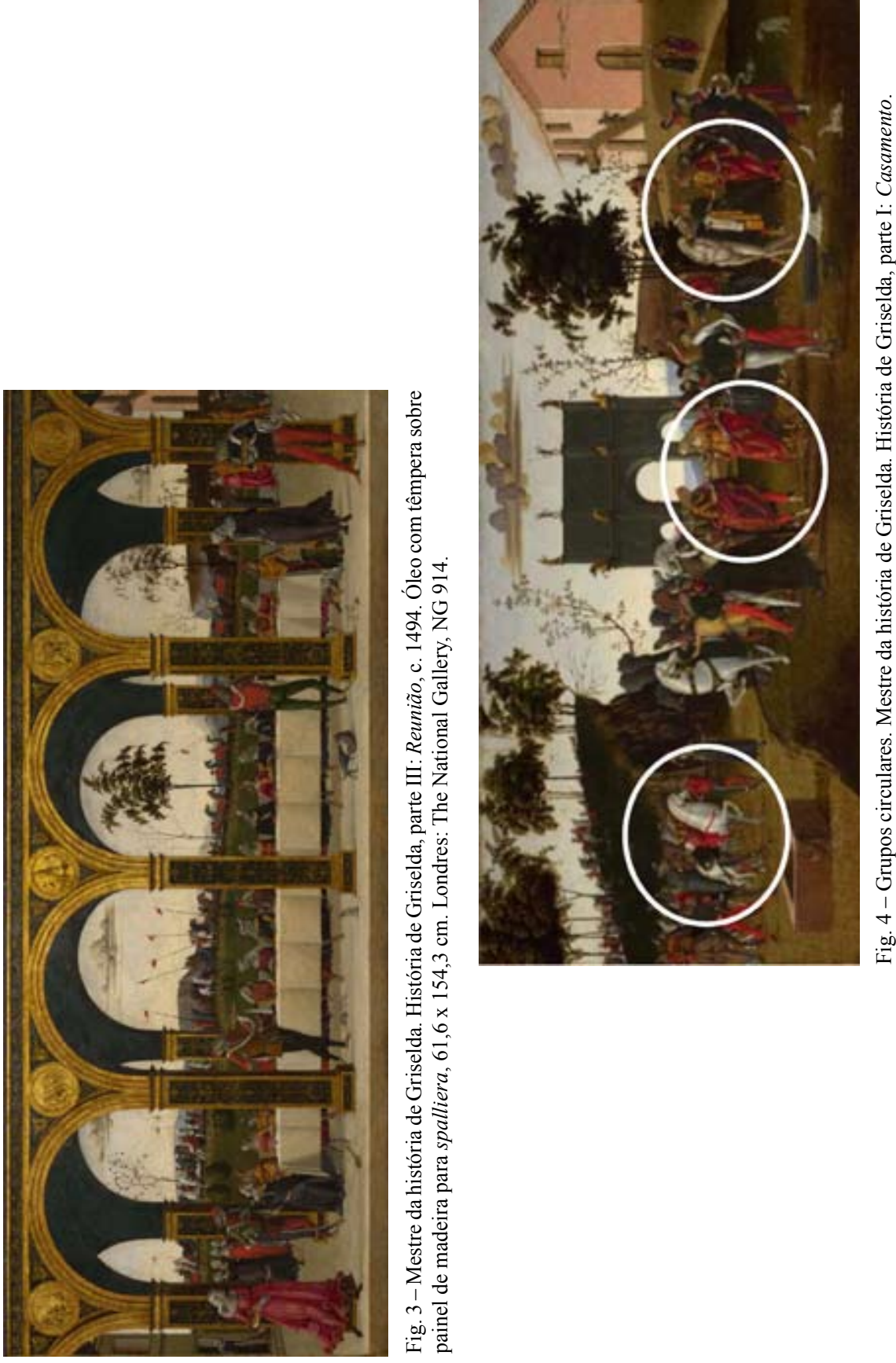

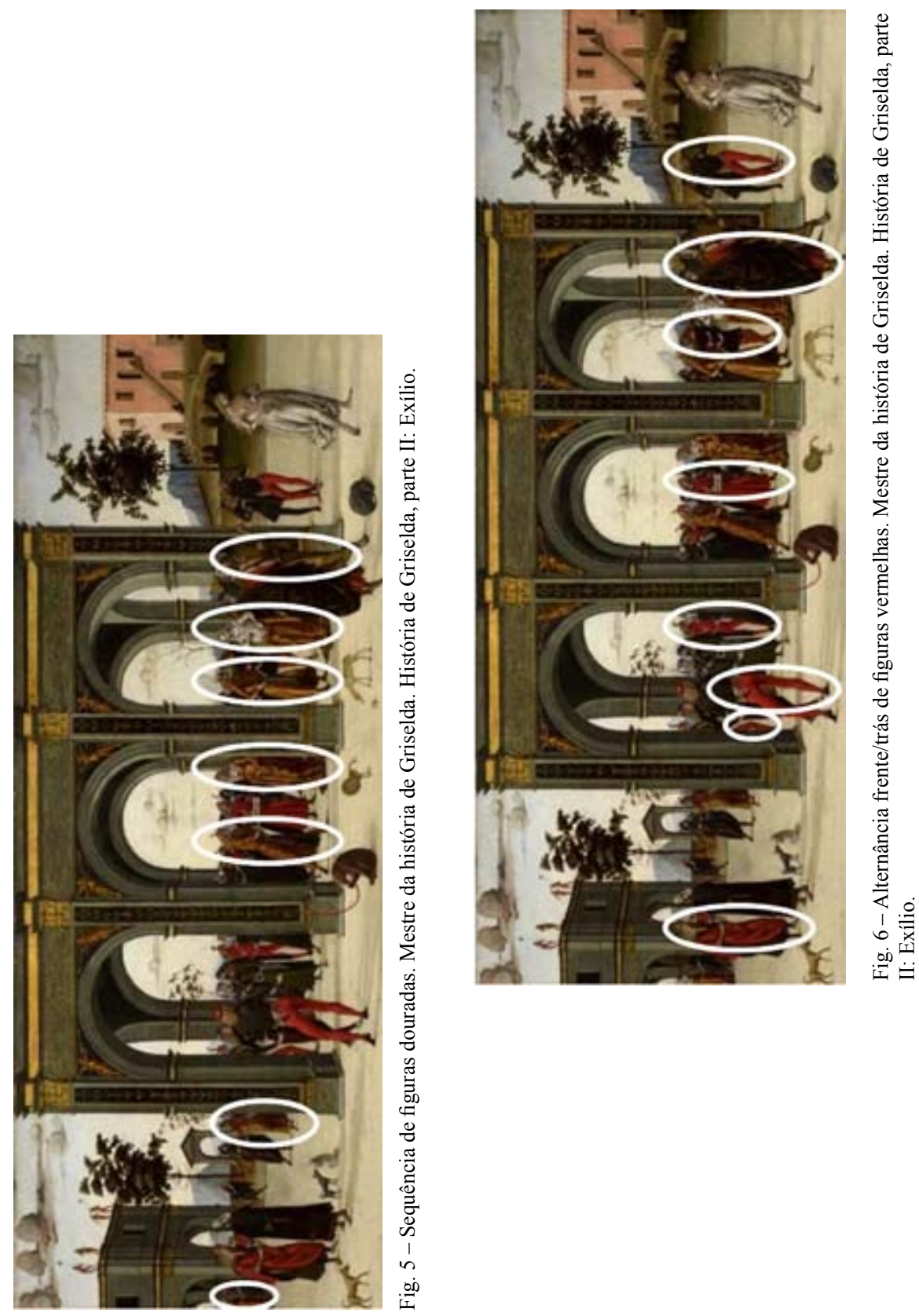


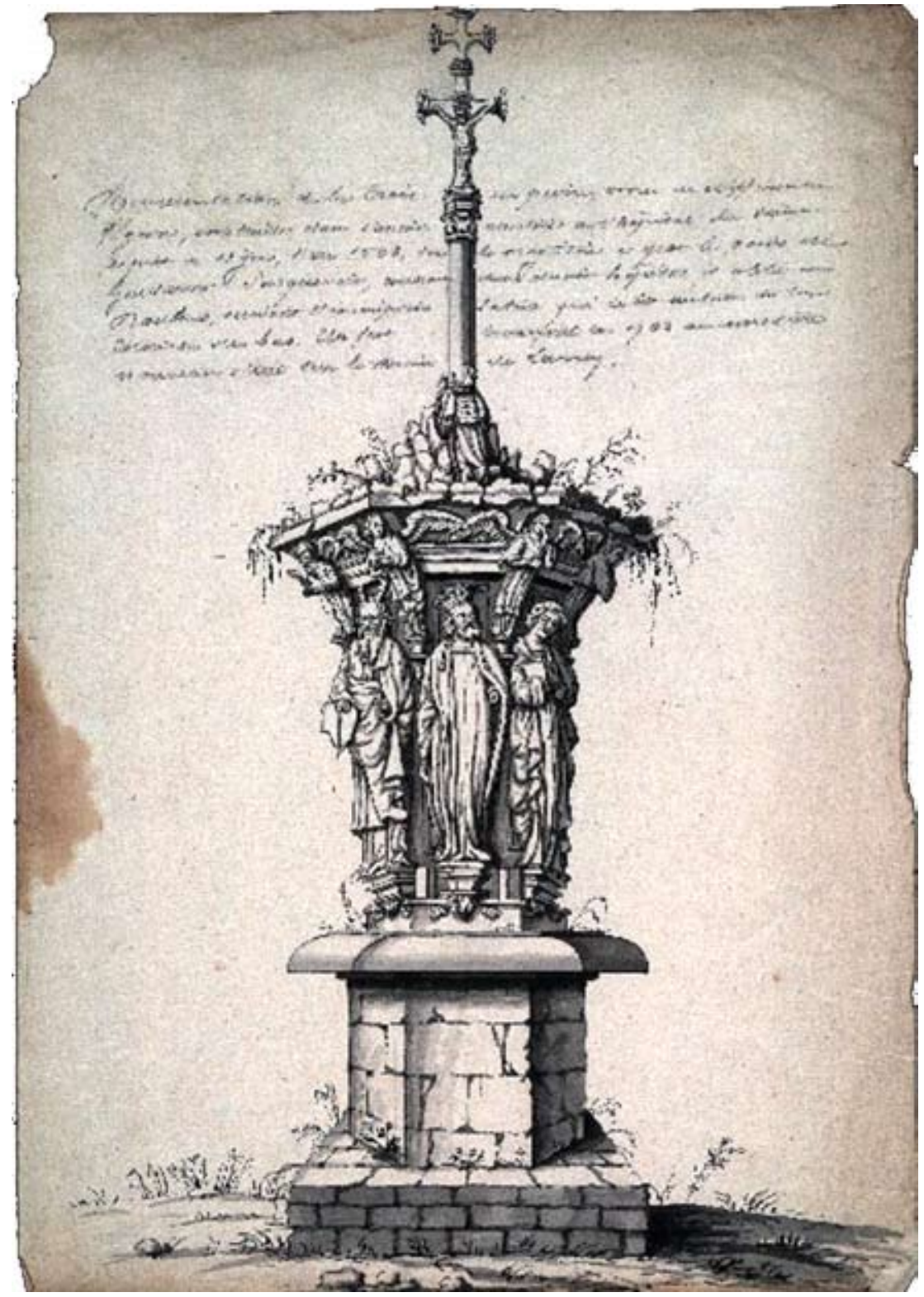

Fig. 1 - O Poço do Hospital do Espírito Santo [Poço de Moisés]. Desenho do séc. XVIII. Archives Départamentales de la Cote d'Or, J2476/3. 
Paloma Lima Santos MARIANO. Caderno de Imagens.

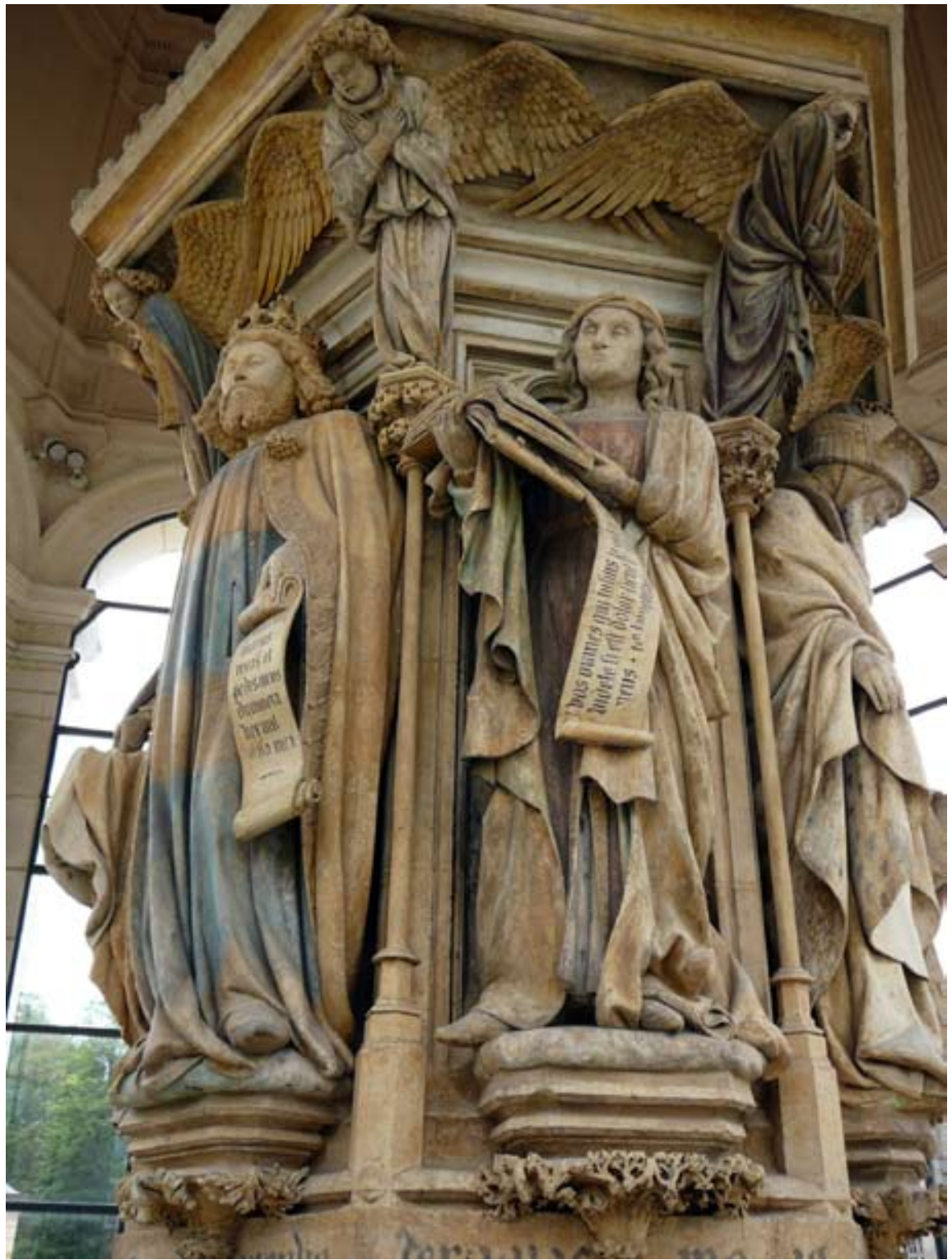

Fig. 2 - Poço de Moisés. Fotografia Paloma Lima e Maria Cristina Pereira, 2010. 
Paloma Lima Santos MARIANO. Caderno de Imagens.

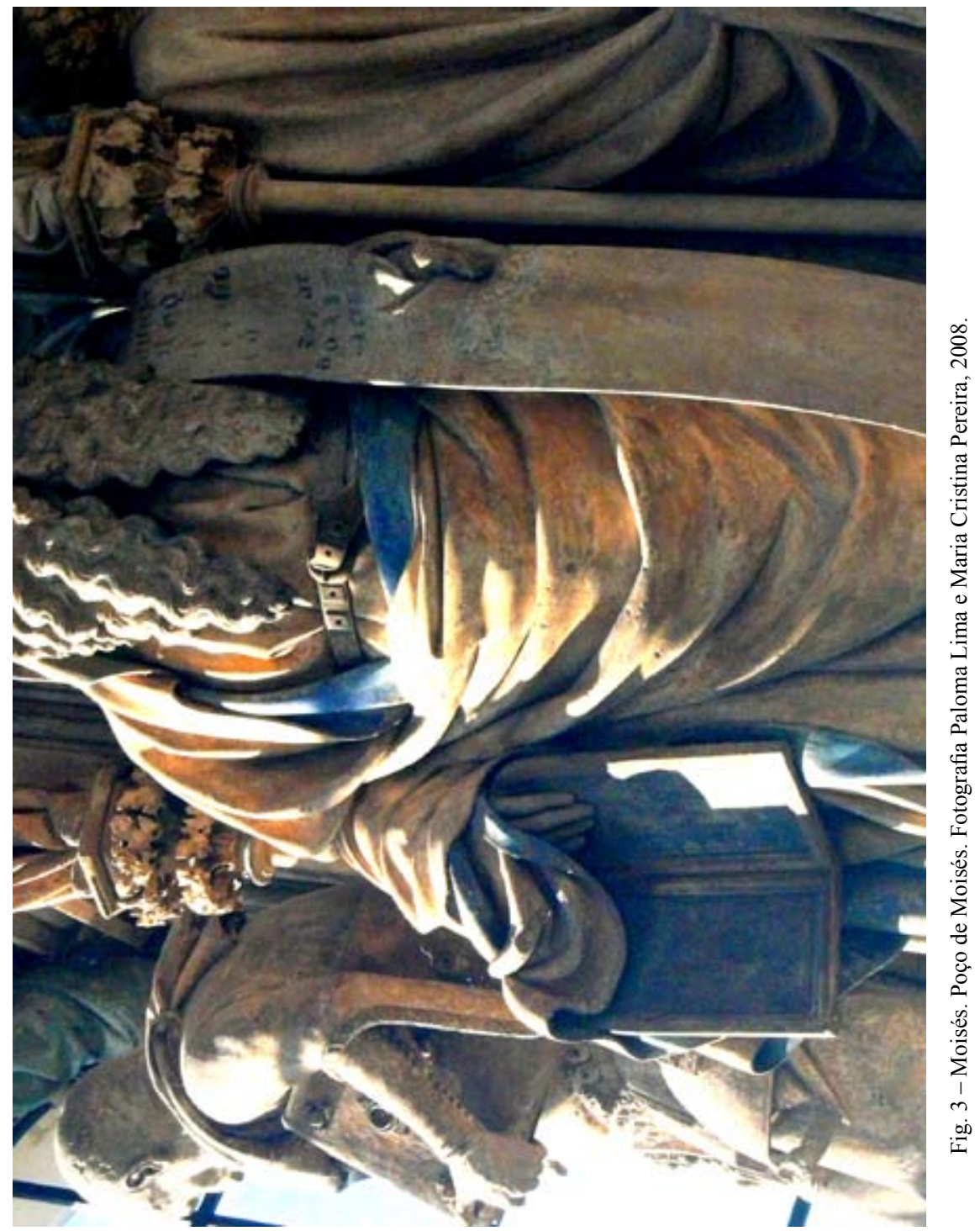



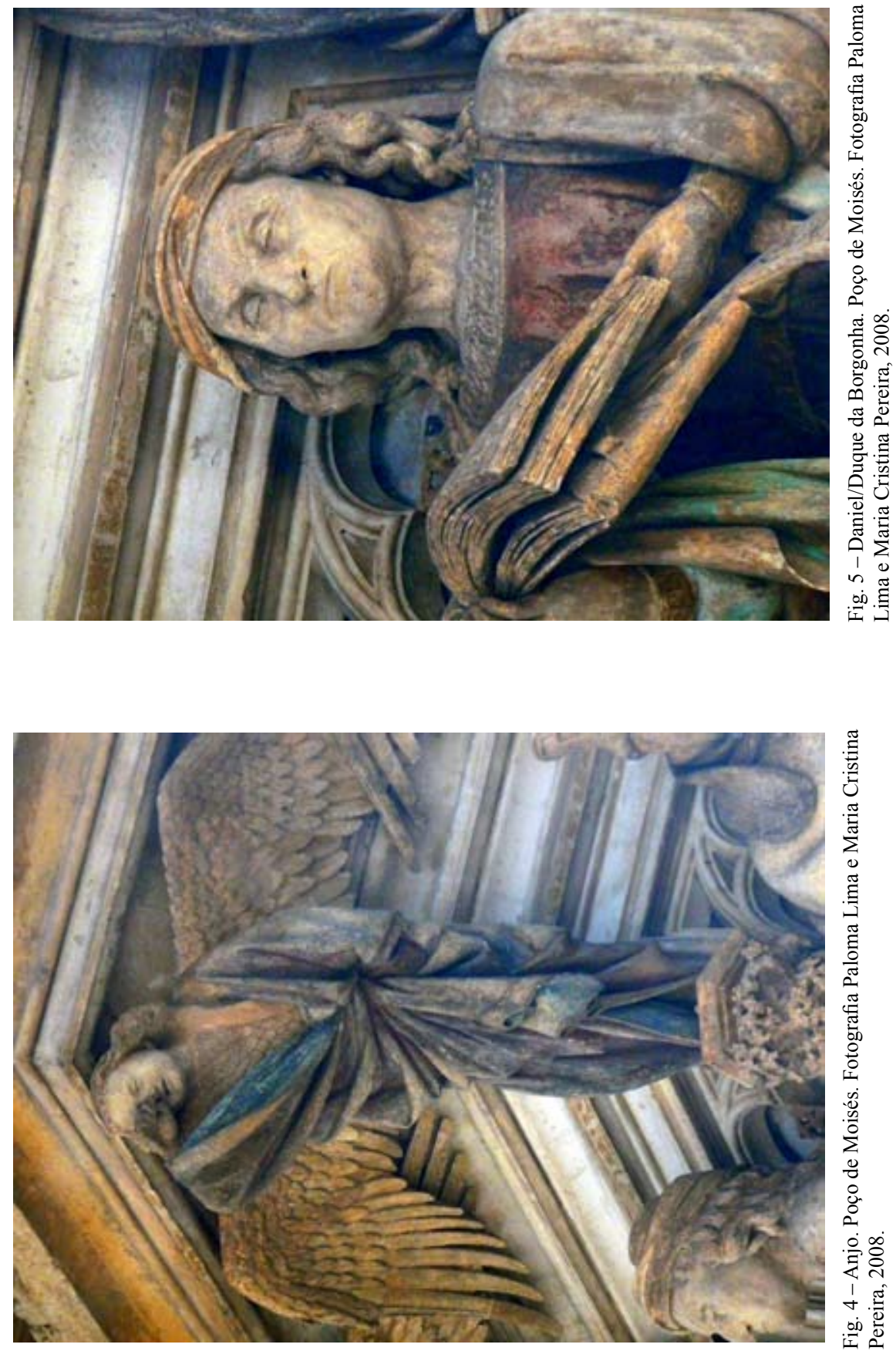